\title{
The Self-Assembly of a Cyclometalated Palladium Photosensitizer into Protein-Stabilized Nanorods Triggers Drug Uptake In Vitro and In Vivo
}

Xue-Quan Zhou, Ming Xiao, Vadde Ramu, Jonathan Hilgendorf, Xuezhao Li, Panagiota Papadopoulou, Maxime A. Siegler, Alexander Kros, Wen Sun,* and Sylvestre Bonnet*

Cite This: J. Am. Chem. Soc. 2020, 142, 10383-10399

Read Online

ACCESS | Lلll Metrics \& More | 回 Article Recommendations

Supporting Information

ABSTRACT: Enhanced passive diffusion is usually considered to be the primary cause of the enhanced cellular uptake of cyclometalated drugs because cyclometalation lowers the charge of a metal complex and increases its lipophilicity. However, in this work, monocationic cyclometalated palladium complexes [1] OAc $\left(\mathbf{N}^{\wedge} \mathbf{N}^{\wedge} \mathbf{C}^{\wedge} \mathbf{N}\right)$ and [2] OAc $\left(\mathbf{N}^{\wedge} \mathbf{N}^{\wedge} \mathbf{N}^{\wedge} \mathrm{C}\right)$ were found to self-assemble, in aqueous solutions, into soluble supramolecular nanorods, while their tetrapyridyl bicationic analogue $[3](\mathbf{O A c})_{2} \quad\left(\mathbf{N}^{\wedge} \mathbf{N}^{\wedge} \mathbf{N}^{\wedge} \mathbf{N}\right)$ dissolved as isolated molecules. These nanorods formed via metallophilic $\mathrm{Pd} \cdots \mathrm{Pd}$ interaction and $\pi-\pi$ stacking and were stabilized in the cell medium by serum proteins, in the absence of which the nanorods precipitated. In cell cultures, these protein-stabilized self-assembled nanorods were responsible for the improved cellular uptake of the cyclometalated compounds, which took

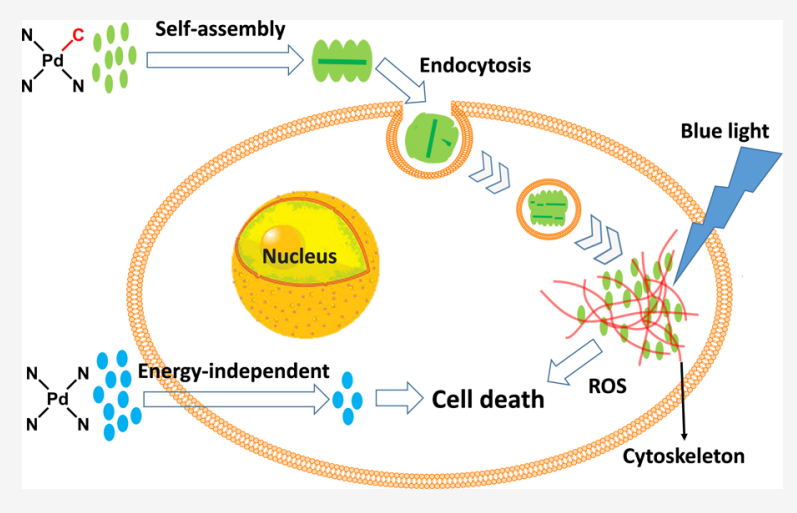
place via endocytosis (i.e., an active uptake pathway). In addition to triggering self-assembly, cyclometalation in [1] OAc also led to dramatically enhanced photodynamic properties under blue light irradiation. These combined penetration and photodynamic properties were observed in multicellular tumor spheroids and in a mice tumor xenograft, demonstrating that protein-stabilized nanoaggregation of cyclometalated drugs such as [1] OAc also allows efficient cellular uptake in 3D tumor models. Overall, serum proteins appear to be a major element in drug design because they strongly influence the size and bioavailability of supramolecular drug aggregates and hence their efficacy in vitro and in vivo.

\section{INTRODUCTION}

Research on metal-based anticancer drugs has been encouraged for many years by the clinical success of cisplatin, carboplatin, oxaliplatin, and nedaplatin, four metal-based drugs used in the treatment of cancer. ${ }^{1-3}$ However, the similar mode of action of these platinum-based compounds, where aquation of some of the leaving groups by intracellular water leads to nonselective covalent binding of platinum to DNA, results in significant side effects and drug resistance. ${ }^{3-10}$ Several strategies have been developed to overcome these drawbacks, in particular, photodynamic therapy (PDT). PDT is a fastdeveloping cancer treatment modality because it shows reduced systemic cytotoxicity to cancer patients. ${ }^{11-13}$ In PDT, a photosensitizing agent (PS) is injected, and upon light at the tumor site, cytotoxic reactive oxygen species (ROS) are generated via a so-called type I (electron transfer) mechanism or via a type II (energy transfer) pathway. ${ }^{14-19}$ These two competing pathways may also occur simultaneously, and the ratio between these processes depends on many parameters such as the type of PS used, the concentrations of substrate and dioxygen, and the localization of the photosensitizer. $^{14,16}$ In the design of new PSs, metal complexes derived from heterocyclic ligands, especially polypyridyl ligands, have attracted a great amount of attention for their tunable photophysical properties and their visible light absorption, which greatly improve the light penetration of biological tissues compared to that of UV-light-sensitive molecules. $^{13,20-24}$ Short-wavelength (blue or green) PDT agents, although traditionally considered to be academic curiosities due to the low tissue penetration of this type of visible light, are regaining interest for certain cancers of thin organs, such as skin and bladder, because the thickness of the tumors in such cancers matches the penetration depth of blue light and green light well. ${ }^{25}$

More particularly, cyclometalated metal complexes, in which a metal-nitrogen bond is replaced by a metal-phenylene

Received: February 4, 2020

Published: May 7, 2020 
bond, have been considered to be a way to improve the efficiency of metal-based PDT sensitizers. Cyclometalated complexes are indeed known for the significant red shift of their absorption maxima compared to that of polypyridyl analogues, enhanced stability in solution, and improved cellular uptake. $^{26}$ The latter is usually claimed to be due to their decreased charge and increased lipophilicity compared to those of polypyridyl analogues. ${ }^{20,26}$ However, little is known of the cyclometalated metal complexes' fate in cell media, which is a complex mixture of many small biological molecules and proteins. $^{27}$ These biomolecules might interact with cyclometalated complexes to generate either new molecular species or supramolecular aggregates, resulting in modified cellular uptake and biological properties. ${ }^{28,29}$ Recently, Thomas's group reported a series of cyclometalated $\left[\mathrm{Ir}^{\mathrm{III}} \mathrm{Ru}^{\mathrm{II}}\right]^{3+}$ luminescent DNA imaging probes that were prevented to penetrate the nuclei of cancer cells by reaction with the serum albumin present in cell growing media, while their polypyridyl analogue $\left[\mathrm{Ir}^{\mathrm{III}} \mathrm{Ru}^{\mathrm{II}}\right]^{4+}$ retained nuclear staining properties in serum-containing media. ${ }^{30}$ Che's group also reported a selfassembled platinum/gold system for controlled drug release and accumulation in tumors. ${ }^{31}$ Coincidentally, many cyclometalated complexes in the literature have been shown to produce fluorescent dots in the cytoplasm and not to reach the nucleus, ${ }^{31-33}$ an organelle that selectively sorts out particles of small sizes. $^{34}$

Palladium(II) complexes have been proposed as possible analogues of antitumor platinum complexes for their similar $\mathrm{d}^{8}$ coordination sphere and tetradentate square-planar structure. Recently, two palladium-based PDT sensitizers, Padoporfin and its derivative Padeliporfin, have been clinically approved to treat prostate cancer, which demonstrates the potential of palladium complexes for PDT. ${ }^{15,35}$ Encouraged by these developments, our group recently studied the influence of the position of the $\mathrm{Pd}-\mathrm{C}$ bond in cyclometalated palladium complexes based on tetrapyridyl ligand Hbbpya ( $N, N$-bis $\left(2,2^{\prime}\right.$ bipyrid-6-yl)amine) with respect to their photodynamic properties. $^{36}$ The isomer characterized by a $\mathrm{Pd}-\mathrm{C}$ bond on the side of the noncoordinated $\mathrm{NH}$ bridge of this ligand shows better blue-light absorption and a better singlet oxygen generation ability compared to the isomer where the $\mathrm{Pd}-\mathrm{C}$ bond lies further from the $\mathrm{NH}$ bridge. However, in these complexes the deprotonation of the noncoordinated $\mathrm{NH}$ bridge becomes easy upon palladation of the ligand, resulting in insoluble neutral metal complexes, thus limiting their application for cancer treatment in vivo. In this work, we methylated this $\mathrm{NH}$ bridge and synthesized three analogous palladium complexes: cyclometalated isomers [1] OAc $\left(\mathrm{N}^{\wedge} \mathrm{N}^{\wedge} \mathrm{C}^{\wedge} \mathrm{N}\right.$ coordination) and $[2] \mathbf{O A c}\left(\mathrm{N}^{\wedge} \mathrm{N}^{\wedge} \mathrm{N}^{\wedge} \mathrm{C}\right.$ coordination), and the reference tetrapyridyl complex $[3](\mathbf{O A c})_{2}$ $\left(\mathrm{N}^{\wedge} \mathrm{N}^{\wedge} \mathrm{N}^{\wedge} \mathrm{N}\right.$ coordination, Scheme 1). All palladium complexes, prepared with acetate counterions, were water-soluble.

\section{Scheme 1. Structures of the Metal Complexes}

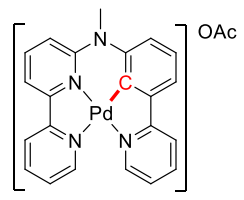

[PdMeL ${ }^{1}$ ]OAC [1]OAC

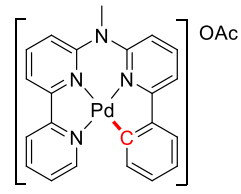

[PdMeL $\left.{ }^{2}\right] \mathrm{OAc}$ [2]OAC

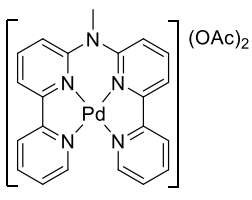

$\left[\mathrm{PdMeL}^{3}\right](\mathrm{OAc})_{2}$ $[3](\mathrm{OAc})_{2}$
With this new series of complexes at hand, it was possible to address the influences of cyclometalation and isomerism on the aggregation and fate of these metal complexes in vitro and in vivo and to study how proteins present in serum influenced their speciation and uptake.

\section{EXPERIMENTAL SECTION}

Compound Preparations. The starting materials and precursors $\mathbf{H L}^{1}-\mathbf{H L}^{3}$ were prepared according to literature methods. ${ }^{36}$ The preparation details of ligands $\mathbf{M e L}^{1}, \mathbf{M e L}^{2}$, and $\mathbf{M e L}^{3}$ and corresponding metal complexes $\left[\mathbf{P d M e L}^{1}\right] \mathbf{O A c}\left([\mathbf{1}]^{+}\right),\left[\mathbf{P d M e L}^{2}\right]$ OAc $\left([2]^{+}\right)$, and $\left[\mathbf{P d M e L}^{3}\right](\mathbf{O A c})_{2}\left([3]^{2+}\right)$ are given in the Supporting Information (SI). All solvents and reagents were purchased from commercial vendors and used without purification. All synthesis was performed in a dinitrogen atmosphere. The metal complexes were synthesized and purified without column chromatography in high yields. In the subsequent report, the complexes are all in the $\mathrm{CH}_{3} \mathrm{COO}^{-}$counterion unless otherwise specified.

Partition Coefficient $\left(\log P_{\text {ow }}\right)$ Determination. The partition coefficients of palladium complexes were determined by the shakeflask method. In brief, the palladium complexes were dissolved in octanol-saturated water and ultrasonicated for $1 \mathrm{~h}$ to prepare $1 \mathrm{mM}$ stock solutions. After filtering with a $0.2 \mu \mathrm{M}$ membrane filter, aliquots of the stock solutions $(0.2 \mathrm{~mL})$ were transferred per duplicate to 15 $\mathrm{mL}$ centrifuge tubes and diluted up to $1 \mathrm{~mL}$ using octanol-saturated water. Then, $1 \mathrm{~mL}$ of water-saturated octanol was added to one of the tubes, and the mixtures were shaken in an IKA Vibrax shaker for $24 \mathrm{~h}$ at $2200 \mathrm{pm}$. The mixture was centrifuged for $20 \mathrm{~min}$ at $4300 \mathrm{rpm}$ to separate the water phase. An aliquot of the water phase $(0.4 \mathrm{~mL})$ was first mixed with $0.8 \mathrm{~mL}$ of $65 \% \mathrm{HNO}_{3}$ and then diluted with Milli-Q water $(4.8 \mathrm{~mL})$ to make an $8.7 \% \mathrm{HNO}_{3}$ solution $(6 \mathrm{~mL})$. The palladium content of these samples was determined by ICP-OES using a Vista-MPX CCD simultaneous ICP-OES. Partition coefficient $\log P_{\text {ow }}$ was calculated using the equation below

$$
\log P_{\text {ow }}=\log \left([\mathrm{Pd}]_{\mathrm{oct}} /[\mathrm{Pd}]_{\mathrm{aq}}\right)=\log \left([\mathrm{Pd}]_{\mathrm{total}}-[\mathrm{Pd}]_{\mathrm{aq}}\right) /[\mathrm{Pd}]_{\mathrm{aq}}
$$

where $[\mathrm{Pd}]_{\text {total }}$ is the concentration of palladium in the control sample (where no water-saturated octanol was added) and $[\mathrm{Pd}]_{\mathrm{aq}}$ is the concentration of palladium in the aqueous layer.

Single-Crystal X-ray Crystallography. The $\mathrm{CH}_{3} \mathrm{COO}^{-}$ counterion of $[1]^{+}$and $[2]^{+}$was changed to the $\mathrm{PF}_{6}{ }^{-}$ion by adding excess $\mathrm{KPF}_{6}$ to a water solution of the acetato metal complexes to obtain a precipitate of $[\mathbf{1}] \mathbf{P F}_{6}$ and $[2] \mathbf{P F}_{6}$ that was filtered off and dried. Single crystals suitable for $\mathrm{X}$-ray structure determination were obtained for $[1] \mathbf{P F}_{6}$ and $[2] \mathbf{P F}_{6}$ via slow evaporation of a solution of the metal complex $\left(\mathrm{PF}_{6}\right.$ counterion) in a MeCN/EtOAc mixture $(2: 1)$. Single crystals of $[3] \mathrm{BF}_{4}$ were obtained via vapor diffusion from diethyl ether to a $\mathrm{MeCN} / \mathrm{EtOAc}$ solution of $[3](\mathrm{OAc})_{2}$ containing $\mathrm{HBF}_{4}$. All reflection intensities were measured at $110(2) \mathrm{K}$ using a SuperNova diffractometer (equipped with an Atlas detector) with Mo $\mathrm{K} \alpha$ radiation $(\lambda=0.71073 \AA)$ for $[1] \mathbf{P F}_{6}$ and $[3]\left(\mathbf{B F}_{4}\right)_{2}$ and with $\mathrm{Cu}$ $\mathrm{K} \alpha$ radiation $(\lambda=1.54178 \AA)$ for $[2] \mathbf{P F}_{6}$ via the CrysAlisPro program (Version CrysAlisPro 1.171.39.29c, Rigaku OD, 2017). The same program was used to refine the cell dimensions and to reduce the data. The structure was solved with the SHELXS-2018/3 program (Sheldrick, 2018) and was refined on $F^{2}$ with SHELXL-2018/3 (Sheldrick, 2018). Numerical absorption correction based on Gaussian integration over a multifaceted crystal model was performed using CrysAlisPro. The temperature of the data collection was controlled using the Cryojet system (manufactured by Oxford Instruments). The $\mathrm{H}$ atoms were placed at calculated positions (unless otherwise specified) using the AFIX 43 or AFIX 137 instructions with isotropic displacement parameters having a value of $1.2 U_{\text {eq }}$ or $1.5 U_{\text {eq }}$ for the attached $\mathrm{C}$ atoms. For [2] $\mathbf{P F}_{6}$, the $\mathrm{H}$ atoms attached to $\mathrm{N} 1$ and $\mathrm{N} 21$ were found from difference Fourier maps, and their coordinates were refined pseudofreely. The $\mathrm{H} 1 \cdots \mathrm{H} 21$ distance was set to be found within an acceptable range $(>1.9 \AA)$ using the DFIX instructions. 
Photophysical Property Measurements. Absorption spectra of complexes were recorded on a Cary 50 spectrometer from Varian. The emission spectra and relative phosphorescence quantum yields of metal complexes in aerated water were obtained via a FLS900 spectrometer from Edinburgh Instruments Ltd. The phosphorescence lifetime of complexes in aerated water was measured by LifeSpec-II from Edinburgh Instruments, with an excitation source of a $375 \mathrm{~nm}$ pulsed diode laser (pulse width $<90 \mathrm{ps)}$ ). The relative singlet oxygen quantum yield $\left(\varphi_{\Delta}\right)$ of complexes was measured in deuterated methanol on a special custom-built setup described previously, with $\left[\mathrm{Ru}(\text { bpy })_{3}\right] \mathrm{Cl}_{2}$ (Tris(bipyridine)ruthenium(II) chloride) as the standard $\left(\varphi_{\Delta}=0.73\right) .^{37,38}$ For the measurement of $\varphi_{\Delta}$ in OptiMEM medium, see the Supporting Information.

Calculated Values and TDDFT-Calculated Spectra of Metal Complexes. The structures of complexes $[1]^{+},[2]^{+}$, and $[3]^{2+}$ were minimized by DFT at the PBE0/TZP level for all atoms including Pd, as implemented in the ADF2017 suite from SCM, using COSMO to simulate solvent effects (in water), scalar relativistic effects for Pd, no frozen core, and starting from the X-ray structures of $[1] \mathbf{P F}_{6}$ and [2] $\mathbf{P F}_{6}$. The 20 first singlet-to-singlet electronic transitions were also calculated with TDDFT using ADF2017 and at the same level of theory using the Davidson method. Dimer $\left\{[1]^{+}\right\}_{2}$ was minimized at the same level of theory as monomer $[\mathbf{1}]^{+}$.

Aggregation of Metal Complexes in Different Aqueous Solutions According to Dynamic Light Scattering (DLS). DLS was chosen to determine the numbers and sizes of particles in complex solutions ( 5 and $50 \mu \mathrm{M}$ ) in $\mathrm{H}_{2} \mathrm{O}$, PBS, and Opti-MEM medium with and without FCS (fetal calf serum) proteins via the ZEN1600 Zetasizer Nano instrument (Malvern Instruments Limited) operating with a $633 \mathrm{~nm}$ laser.

Transmission Electron Microscopy (TEM) Measurement of Metal Complexes in Different Solutions. The TEM experiments were carried out with a TEM JEOL 1010:100 kV transmission electron microscope using a Formvar/carbon-coated copper grid from Polysciences Inc. For the preparation of samples, each drop $(15 \mu \mathrm{L})$ of complex solution was deposited on parafilm. The grids were placed on top of the drops for $2 \mathrm{~min}$, and then the excess liquid on the grid was removed with filter paper and dried for $2 \mathrm{~h}$ for TEM measurement. The TEM measurements were carried out under vacuum conditions.

Cryogenic Transmission Electron Microscopy (Cryo-TEM) Measurements. Sample $(6 \mu \mathrm{L}$, [complex] $=50 \mu \mathrm{M})$ was applied to a freshly glow-discharged carbon 200 mesh $\mathrm{Cu}$ grid (lacey carbon film, Electron Microscopy Sciences, Aurion, Wageningen, The Netherlands). Grids were blotted for $3 \mathrm{~s}$ at $99 \%$ humidity in a Vitrobot plunge-freezer (FEI VitrobotTM Mark III, Thermo Fisher Scientific). Cryo-TEM images were collected on a Talos L120C ( $\mathrm{NeCEN}$, Leiden University) operating at $120 \mathrm{kV}$. Images were recorded manually at a nominal magnification of $4300 \times$ or $13500 \times$ yielding a pixel size at the specimen of 29.9 or $5.9 \AA$, respectively.

Cell Culture. Cells were thawed and at least passaged twice before starting cytotoxicity experiments. For normoxia experiments, cells were cultured in DMEM completed medium (Dulbecco's Modified Eagle Medium with phenol red, supplemented with $8.0 \% \mathrm{v} / \mathrm{v}$ fetal calf serum (FCS), $0.2 \% \mathrm{v} / \mathrm{v}$ penicillin/streptomycin $(\mathrm{P} / \mathrm{S})$, and $1 \% \mathrm{v} / \mathrm{v}$ glutamine) under humidified normoxic conditions $\left(37{ }^{\circ} \mathrm{C}\right.$ atmosphere, $21 \% \mathrm{O}_{2}$ and $\left.7.0 \% \mathrm{CO}_{2}\right)$ in $75 \mathrm{~cm}^{2}$ flasks. They were subcultured upon reaching $70-80 \%$ confluence, approximately once per week. Cells were passaged for never more than 8 weeks. For the cytotoxicity assay, Opti-MEM complete medium without phenol red was used, supplemented with $2.5 \% \mathrm{v} / \mathrm{v}$ fetal calf serum (FCS), $0.2 \%$ $\mathrm{v} / \mathrm{v}$ penicillin/streptomycin $(\mathrm{P} / \mathrm{S})$, and $1 \% \mathrm{v} / \mathrm{v}$ glutamine). For hypoxia cytotoxicity experiments, cells were cultured in DMEM complete medium for at least 2 weeks under humidified hypoxic conditions $\left(37{ }^{\circ} \mathrm{C}\right.$ atmosphere, $1.0 \% \mathrm{O}_{2}$, and $7.0 \% \mathrm{CO}_{2}$ ) before starting hypoxic cytotoxicity tests.

Photocytotoxicity Assay. The working solutions of the three complexes were typically prepared from $1.0 \mathrm{mM}$ stock solutions of the complex in distilled water. The cell irradiation system consists of a Ditabis thermostat (980923001) fitted with two flat-bottomed microplate thermoblocks (800010600) and a 96-LED array fitted to a standard 96-well plate. The $455 \mathrm{~nm}$ LED (FNL-U501B22WCSL), fans (40 mm, 24 V DC, 9714839), and power supply (EA-PS 204206B) were ordered from Farnell. A full description of the cell irradiation setup is given in Hopkins et al. ${ }^{39}$ The photocytotoxicity assay was carried out via the sulforhodamine B (SRB) assay reports. ${ }^{40}$ Briefly, a certain number of cells (5000 cells for A549, 8000 cells for A431) were seeded in 96-well plates at $t=0$ in a volume of $100 \mu \mathrm{L}$ of Opti-MEM complete medium without phenol red and incubated for $24 \mathrm{~h}$ under normoxic $\left(21 \% \mathrm{O}_{2}\right)$ or hypoxic $\left(1 \% \mathrm{O}_{2}\right)$ conditions. The cells were treated with a freshly prepared solution of the complexes in Opti-MEM at different concentrations in triplicate on the same plates at $t=24 \mathrm{~h}$. The concentrations of complexes were tuned depending on their cytotoxicity. At $t=48 \mathrm{~h}$, the irradiation plates were irradiated with blue light under normoxic $\left(455 \mathrm{~nm}, 5 \mathrm{~min}, 5.66 \mathrm{~mW} \mathrm{~cm}^{-2}, 1.7 \mathrm{~J}\right.$ $\mathrm{cm}^{-2}$ ) or hypoxic $\left(455 \mathrm{~nm}, 8 \mathrm{~min}, 3.54 \mathrm{~mW} \mathrm{~cm} \mathrm{~cm}^{-2}, 1.7 \mathrm{~J} \mathrm{~cm}^{-2}\right.$ ) conditions, while the dark plates were kept nonirradiated. After light irradiation, all plates were incubated in the dark for another $48 \mathrm{~h}$ under normoxic or hypoxic conditions, respectively. Then, the cells in each well were fixed with trichloroacetic acid (TCA, 10\% w/v), gently washed with distilled water, and stained with $100 \mu \mathrm{L}$ of SRB $(0.6 \% \mathrm{w} /$ $\mathrm{v}$ in $1 \% \mathrm{v} / \mathrm{v}$ acetic acid $/ \mathrm{H}_{2} \mathrm{O}$ solution). The SRB dye was then solubilized with Tris base $(10 \mathrm{mM}, 200 \mu \mathrm{L})$, and the absorbance in each well was read at $510 \mathrm{~nm}$ using a M1000 Tecan Reader. Three independent biological replicates were completed for each cell line. The obtained data were analyzed with Graphpad Prism 5 using the dose-response two-parameter Hill slope equation (eq 1) to obtain the half-maximal effective concentrations $\mathrm{EC}_{50}$ (defined as the concentration of drug that gives a half-maximum effect).

$$
\mathrm{Y}=100 /\left(1+10^{\left.\left(\operatorname{(og}_{10} \mathrm{EC}_{50}-X\right) \times \text { Hill slope }\right)}\right)
$$

Cellular Uptake Inhibition. A549 cells $\left(5 \times 10^{5}\right.$ cells $)$ were seeded in six-well plates, incubated for $24 \mathrm{~h}$ under normoxic conditions, and then treated with $\mathrm{NaN}_{3}$ (active uptake inhibitor, $15.4 \mathrm{mM}$ ) or dynasore (dynamin-dependent endocytosis inhibitor, 80 $\mu \mathrm{M}$ ) for $1 \mathrm{~h}$; after that, the cells were incubated with one of the three palladium complexes $(5 \mu \mathrm{M})$ for $3 \mathrm{~h}$. To remove the surface-bound drug, the cells were first washed thrice using with ice-cold PBS. Then the cells were counted via a cell-counting board three times, collected by centrifugation, and $7 \mathrm{~mL}$ of cell lysis buffer (RIPA Lysis and Extraction Buffer, Thermo Scientific) was added. Ultrasonication was then realized for $3 \mathrm{~h}$ at $37^{\circ} \mathrm{C}$ to afford clear samples. If precipitation was still observed, $\mathrm{HNO}_{3}(65 \% 1 \mathrm{~mL})$ was added to the samples, and the sample was heated for $6 \mathrm{~h}$ at $100{ }^{\circ} \mathrm{C}$ with a parafilm on the top to prevent solution evaporation. Once back at room temperature, each sample was then diluted with Milli- $\mathrm{Q}$ water to reach a volume of 10 $\mathrm{mL}$; this solution was finally injected into a PerkinElmer NexION 2000 ICP-MS to measure the Pd concentration.

Cellular Uptake and Localization. A549 cells $\left(5 \times 10^{5}\right.$ cells $)$ were seeded in T-75 flasks, incubated for $24 \mathrm{~h}$ in Optimum medium at $37{ }^{\circ} \mathrm{C}$ under $5 \% \mathrm{CO}_{2}$, and then treated with complexes [1] OAc-[3]$(\mathrm{OAc})_{2}(1 \mu \mathrm{M}, 15 \mathrm{~mL})$, and the control groups were treated with equal volumes of medium. After $24 \mathrm{~h}$ of incubation under normoxic conditions, the cells were washed with ice-cold PBS $(20 \mathrm{~mL})$ three times and then collected in a $15 \mathrm{~mL}$ centrifuge tube and diluted to 10 $\mathrm{mL}$ with ice-cold PBS. Then the cells were counted via a cell-counting board three times. Then the Pd contents of the cells were determined by ICP-MS using the same protocol as described above. For cellular fractionation, a FractionPREP Cell Fractionation Kit was used according to the supplier's instructions to prepare the cytosol, membranes, nucleus, and cytoskeleton fractions using the other half of the cell lysis solution. The samples in each fraction were used directly to detect the Pd content by ICP-MS.

Measurement of Intracellular ROS. The generation of ROS (reactive oxygen species) in A549 cells was measured using ROS fluorescence indicator 2,7-dichlorodihydrofluorescein diacetate (DCFH-DA). ${ }^{19}$ After acetate cleavage by cellular esterases, DCFHDA can be oxidized by ROS to $2^{\prime}, 7^{\prime}$-dichlorofluorescein (DCF), which exhibits strong green fluorescence that can be detected by 
Table 1. Selected Bond Distances (Angstroms) and Angles (Degrees) in the Crystal Structures of $[1] \mathrm{PF}_{6},[2] \mathrm{PF}_{6}$, and $[3]\left(\mathrm{BF}_{4}\right)_{2}$

\begin{tabular}{llllll}
\multicolumn{1}{c}{$\mathbf{1}] \mathrm{PF}_{\mathbf{6}}$} & \multicolumn{1}{c}{$[\mathbf{2}] \mathbf{P F}_{\mathbf{6}}$} & & {$[3]\left(\mathbf{B F}_{4}\right)_{2}$} & \\
$\mathrm{Pd}-\mathrm{N} 1$ & $2.1086(17)$ & $\mathrm{Pd}-\mathrm{N} 1$ & $2.0544(18)$ & $\mathrm{Pd}-\mathrm{N} 1$ & $2.048(2)$ \\
$\mathrm{Pd}-\mathrm{N} 2$ & $1.9860(19)$ & $\mathrm{Pd}-\mathrm{N} 2$ & $2.0435(18)$ & $\mathrm{Pd}-\mathrm{N} 2$ & $1.979(2)$ \\
$\mathrm{Pd}-\mathrm{C} 17$ & $1.9786(18)$ & $\mathrm{Pd}-\mathrm{N} 4$ & $2.0096(18)$ & $\mathrm{Pd}-\mathrm{N} 4$ & $1.983(2)$ \\
$\mathrm{Pd}-\mathrm{N} 4$ & $2.0912(18)$ & $\mathrm{Pd}-\mathrm{C} 22$ & $2.019(2)$ & $\mathrm{Pd}-\mathrm{N} 5$ & $2.034(2)$ \\
$\mathrm{Pd}-\mathrm{Pd}$ & $4.223,3.353$ & $\mathrm{Pd}-\mathrm{Pd}$ & $4.316,3.275$ & $\mathrm{Pd}-\mathrm{Pd}$ & $6.814,8.373$ \\
$\mathrm{~N} 1-\mathrm{Pd}-\mathrm{N} 2$ & $81.00(7)$ & $\mathrm{N} 1-\mathrm{Pd}-\mathrm{N} 2$ & $80.88(7)$ & $\mathrm{N} 1-\mathrm{Pd}-\mathrm{N} 2$ & $81.75(9)$ \\
$\mathrm{N} 2-\mathrm{Pd}-\mathrm{C} 17$ & $92.19(8)$ & $\mathrm{N} 2-\mathrm{Pd}-\mathrm{N} 4$ & $92.04(7)$ & $\mathrm{N} 2-\mathrm{Pd}-\mathrm{N} 4$ & $92.97(9)$ \\
$\mathrm{C} 17-\mathrm{Pd}-\mathrm{N} 4$ & $80.94(7)$ & $\mathrm{N} 4-\mathrm{Pd}-\mathrm{C} 22$ & $82.33(8)$ & $\mathrm{N} 4-\mathrm{Pd}-\mathrm{N} 5$ & $81.67(9)$ \\
$\mathrm{N} 4-\mathrm{Pd}-\mathrm{N} 1$ & $105.77(7)$ & $\mathrm{C} 22-\mathrm{Pd}-\mathrm{N} 1$ & $104.52(8)$ & $\mathrm{N} 5-\mathrm{Pd}-\mathrm{N} 1$ & $103.64(9)$ \\
\hline
\end{tabular}

fluorescent microscopy or flow cytometry. A549 cells $\left(1 \times 10^{5}\right)$ were seeded into 24-well plates and incubated for $6 \mathrm{~h}$ in the dark. The cells were then treated with $5 \mu \mathrm{M}$ complexes and labeled as dark or blue light groups. After $24 \mathrm{~h}$ of incubation under normoxia, the media were refreshed and the cells were treated with DCFH-DA $(20 \mu \mathrm{M})$ for 30 min at $37{ }^{\circ} \mathrm{C}$. After that, the blue light group was irradiated with 455 $\mathrm{nm}$ blue light for $5 \mathrm{~min}\left(5.66 \mathrm{~mW} \mathrm{~cm} \mathrm{~cm}^{-2}, 1.7 \mathrm{~J} \mathrm{~cm}^{-2}\right)$. Then the cells were washed with PBS twice, harvested, and centrifuged $(3 \mathrm{~min} \times$ $2000 \mathrm{rpm}$ ) to remove supernatant. The cells were resuspended in 200 $\mu \mathrm{L}$ of PBS per well in a 96-well plate. Untreated cells were maintained as negative controls, whereas a $400 \mu \mathrm{M} \mathrm{H}_{2} \mathrm{O}_{2}$ solution in Opti-MEM complete was administered to another set of three wells for $1 \mathrm{~h}$ as a positive control for ROS. The levels of intracellular ROS were examined using the Guava easyCyte HT flow cytometer. Gates were applied over forward scattering, side scattering, and forward scattering area measurements when possible to remove cellular debris and select only for singlet whole cells for further statistical analysis. The GRN-B parameter (488 nm excitation, $525 / 30 \mathrm{~nm}$ emission) was used for fluorescence measurements given its close proximity to the known excitation/emission wavelengths of DCF (498/522 nm, respectively). All flow cytometry data were processed using FlowJ10.

Apoptosis Determination. The apoptosis of A549 cells induced by metal complexes was determined with an Annexin V-FITC/ propidium iodide double-staining assay. The assay was performed according to the manufacturer's (Bio-Connect BV) protocol. A549 cells were seeded in six-well plates with $2 \mathrm{~mL}$ of Opti-MEM complete medium $\left(2 \times 10^{5}\right.$ cells/well $)$, incubated for $6 \mathrm{~h}$, and then treated with the three complexes $(15 \mu \mathrm{M})$ and cisplatin $(15 \mu \mathrm{M})$ for $24 \mathrm{~h}$ in the dark and under normoxia. Then one plate treated with complexes was irradiated for $5 \mathrm{~min}$ with $455 \mathrm{~nm}$ blue light $\left(5.66 \mathrm{~mW} \mathrm{~cm}^{-2}, 1.7 \mathrm{~J}\right.$ $\mathrm{cm}^{-2}$ ), named as the blue light group. The cells were all further incubated in the dark for $24 \mathrm{~h}$ under normoxia, after which cells were harvested and then resuspended in $200 \mu \mathrm{L}$ of $1 \times$ annexin binding buffer (purchased from Sanbio B.V.). The resulting cell suspension $(200 \mu \mathrm{L})$ was stained with $5 \mu \mathrm{L}$ of Annexin-V-FITC and $5 \mu \mathrm{L}$ of propidium iodide (purchased from Sanbio B.V) for $15 \mathrm{~min}$ at room temperature in the dark and then detected by flow cytometry immediately. Parameters GRN-B (488 nm excitation, 525/30 nm emission) and RED-B (488 nm excitation, 661/15 nm emission) were used for fluorescence measurements given their close proximity to the known excitation/emission wavelengths of Annexin V-FITC (494/ $518 \mathrm{~nm})$ and propidium iodide $(535 / 617 \mathrm{~nm})$. All flow cytometry data were processed using FlowJo10.

Three-Dimensional Tumor Spheroid Viability Assay. The cytotoxicity of complex $[1]^{+}$in 3D tumor spheroids was determined with a CellTiter-Glo 3D cell viability assay. ${ }^{41}$ A549 cells (500 cells/ $200 \mu \mathrm{L}$ per well) were added to a 96-well round-bottomed Corning spheroid plate microplate and centrifuged for $6 \mathrm{~min}$ at $800 \mathrm{~g}$ to produce tiny tumor spheroid cores that were incubated under normoxia for $120 \mathrm{~h}$ to generate $3 \mathrm{D}$ tumor spheroids $(658 \pm 52 \mu \mathrm{m}$ diameter) At $t=120 \mathrm{~h}, 100 \mu \mathrm{L}$ of medium was carefully pipetted out from each well while avoiding the pipetting of spheroids; then the spheroids were immediately treated with $100 \mu \mathrm{L}$ of an Opti-MEM complete medium solution of complex $[1]^{+}$with a range of concentrations to reach final concentrations in the wells of $0,2,10$,
$20,40,100$, and $200 \mu \mathrm{M}$. Each concentration was repeated in technical triplicate on the same plate. The spheroids were incubated further under normoxia. At $t=144 \mathrm{~h}$, one plate was irradiated with blue light under air $\left(455 \mathrm{~nm}, 10 \mathrm{~min}, 3.48 \mathrm{~mW} \mathrm{~cm}^{-2}, 2.1 \mathrm{~J} \mathrm{~cm}^{-2}\right)$, and the other was left in the dark in a normoxic incubator. The spheroids were further incubated under normoxia in the dark. At $t=192 \mathrm{~h}$, a CellTiter Glo 3D solution (100 $\mu \mathrm{L} /$ well) was added to each well to stain the 3D tumor spheroids. After 30 min of shaking on an IKA Vibrax shaker at $500 \mathrm{rpm}$ at room temperature, the luminescence in each well was measured with a Tecan microplate reader. Half-maximal effective concentrations $\left(\mathrm{EC}_{50}\right)$ for $3 \mathrm{D}$ tumor spheroid growth inhibition were calculated by fitting the CellTiter Glo3D doseresponse curves using the same nonlinear regression function as in $2 \mathrm{D}$ (eq 1) as implemented in Graphpad Prism 5.

In Vivo Experiments. Tumor-bearing female $\mathrm{BALB} / \mathrm{c}$ mice were originally purchased from Vital River Laboratory Animal Center (Beijing, China). The mice were kept under specific pathogen-free conditions with free access to standard food and water. This study was conducted in accordance with the Guide for the Care and Use of Laboratory Animals published by the U.S. National Institutes of Health (eighth edition, 2011). All protocols for animal studies conformed to the Guide for the Care and Use of Laboratory Animals. All animal experiments were performed in accordance with guidelines approved by the ethics committee of Peking University. The tumor model was established by injecting $1 \times 10^{7}$ of $4 \mathrm{~T} 1$ breast cells suspended in $100 \mu \mathrm{L}$ of PBS into the right flank region of each mouse to obtain a mouse $4 \mathrm{~T} 1$ breast tumor implant. The tumor volume $(V)$ can be calculated with equation $V=L / 2 \times W^{2}$ after measuring the tumor length $(L)$ and width $(W)$ using a vernier caliper. ${ }^{42}$ The mice were randomly divided into six groups (control, $450 \mathrm{~nm}$ light, $[1]^{+}$ dark, $[2]^{+}$dark, $[1]^{+}+450 \mathrm{~nm}$ light, and $[2]^{+}+450 \mathrm{~nm}$ light groups) when the tumor volume reached about $40 \mathrm{~mm}^{3}$. The mice were treated through paracancerous injection with saline (control and 450 nm light groups), $[\mathbf{1}]^{+}(40 \mu \mathrm{M}, 100 \mu \mathrm{L}, 0.01 \mathrm{mg} / \mathrm{kg})$, and [2] ${ }^{+}(40$ $\mu \mathrm{M}, 100 \mu \mathrm{L}, 0.01 \mathrm{mg} / \mathrm{kg})$. One hour after injection, $450 \mathrm{~nm}$ irradiation $\left(50 \mathrm{~mW} \mathrm{~cm}{ }^{-2}, 20 \mathrm{~min}, 60 \mathrm{~J} \mathrm{~cm}^{-2}\right)$ was then carried out in $450 \mathrm{~nm}$ irradiation, $[1]^{+}+450 \mathrm{~nm}$, and $[2]^{+}+450 \mathrm{~nm}$ groups. The tumor volume and body weight of each mouse were measured and recorded, and the average tumor volume and body weight were calculated $(N=3)$ over a period of 10 days.

\section{RESULTS}

Synthesis and Characterization. The three titled palladium complexes, $[1]^{+}-[3]^{2+}$ were synthesized as acetate salts by reacting methylated ligands $\mathbf{M e L}^{\mathbf{1}}, \mathbf{M e L}^{2}$, and $\mathbf{M e L}^{3}$ with palladium acetate (Scheme S1). All complexes were obtained in high yield without chromatography and were characterized by NMR (Figures S7-S12), HRMS, elemental analysis, and single-crystal X-ray diffraction (ESI). The acetate counteranions provided good water solubility and similar log $P_{\text {ow }}$ values of $-1.88,-1.92$, and -1.71 , respectively. These values suggested similar cellular uptake efficacy if the three molecules would remain as monomers in aqueous solutions. It 
a

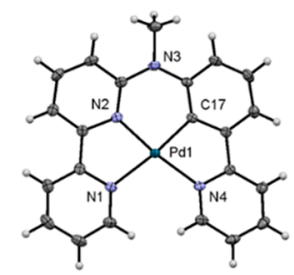

[1]PF

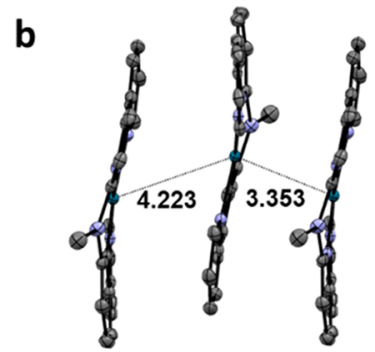

[1] $\mathrm{PF}_{6}$

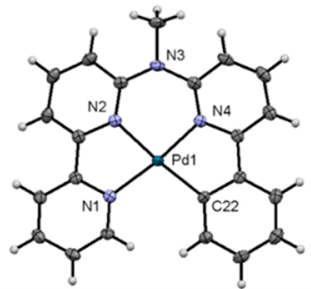

[2] $\mathrm{PF}_{6}$

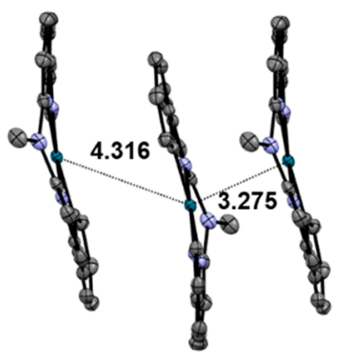

[2] $\mathrm{PF}_{6}$

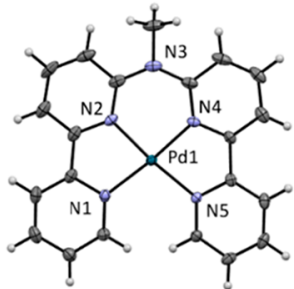

[3] $\left(\mathrm{BF}_{4}\right)_{2}$

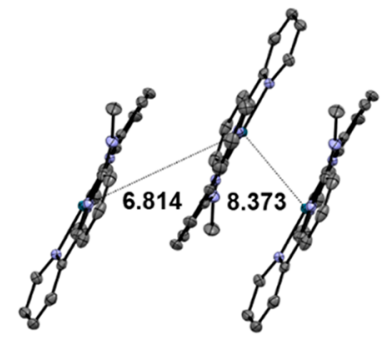

[3] $\left(\mathrm{BF}_{4}\right)_{2}$

Figure 1. Molecular view of the cationic complexes (a) and their stacking (b) in the crystal structures of $[\mathbf{1}] \mathbf{P F}_{6},[2] \mathbf{P F}_{6}$, and $[3]\left(\mathbf{B F}_{4}\right)_{2}$. Displacement ellipsoids are shown at the $50 \%$ probability level. Pd $\cdots$ Pd distances are indicated in angstroms. Counterions and disorder have been omitted for clarity.
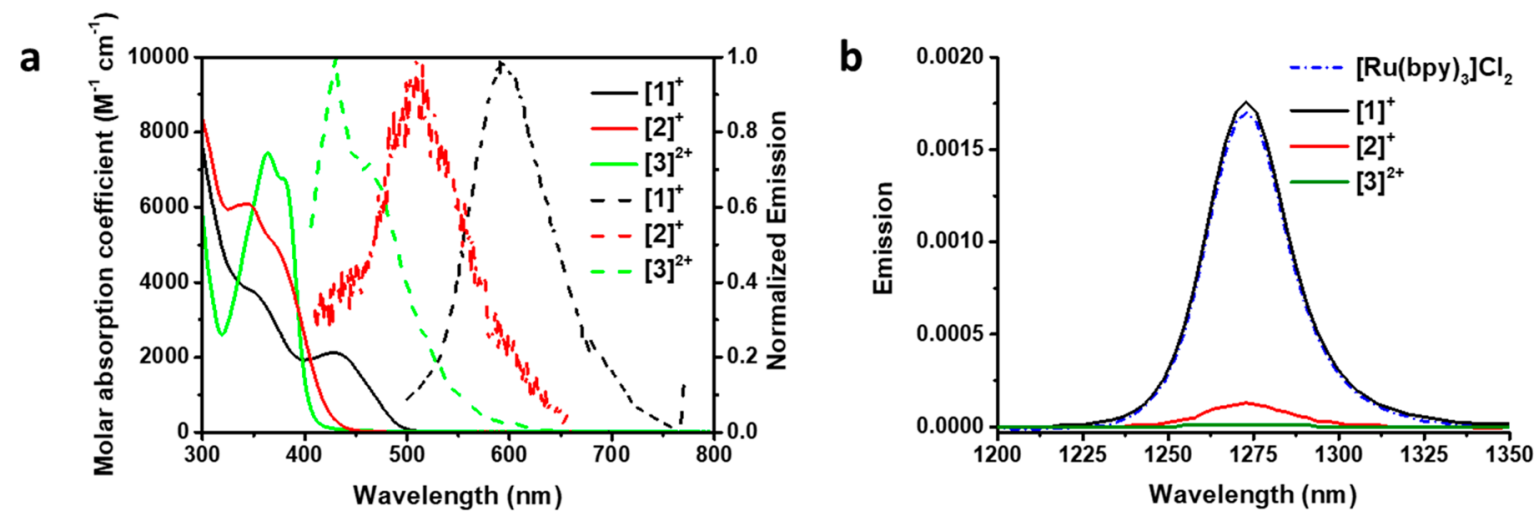

Figure 2. (a) Absorption (solid line, left axis) and normalized emission spectra (dashed line, right axis) of $[1] \mathrm{OAc}-[3](\mathrm{OAc})_{2}$ in water $(50 \mu \mathrm{M}$, $350 \mathrm{~nm}$ excitation). (b) Singlet oxygen emission for solutions of $[1]^{+}-[3]^{2+}$ in $\mathrm{CD}_{3} \mathrm{OD}\left(450 \mathrm{~nm}\right.$ excitation, $\left.A_{450}=0.1\right)$.

is noteworthy that the ${ }^{1} \mathrm{H}$ NMR spectra of cyclometalated complexes $[1]^{+}$and $[2]^{+}$showed significant differences at low and high concentrations, while $[3]^{2+}$ did not show this effect (Figure S13). Thus, NMR suggested that cyclometalation may promote aggregation in this type of complex. ${ }^{43,44}$

Single crystals of $[1] \mathbf{P F}_{6},[2] \mathbf{P F}_{6}$, and $[3]\left(\mathrm{BF}_{4}\right)_{2}$, were obtained by the slow evaporation of a $\mathrm{MeCN} / \mathrm{EtOAc}$ solution or by vapor diffusion from diethyl ether to a $\mathrm{MeCN} / \mathrm{EtOAc}$ solution in presence of $\mathrm{KPF}_{6}$ or $\mathrm{HBF}_{4}(\mathrm{SI})$. The crystals were analyzed by single-crystal X-ray diffraction. Crystallographic data and a selection of interatomic distances and angles are shown in Table $S 1$ and Table 1, respectively. All three complexes crystallized in the triclinic $P \overline{1}$ space group. As shown in Figure 1a, $[\mathbf{1}] \mathbf{P F}_{6}$ and $[2] \mathbf{P F}_{6}$ were coordination isomers, with three nitrogen atom and one carbon atom coordinated to the palladium(II) cation and bond lengths in the range of 1.9786(18)-2.1086(17) A. Four nitrogen atoms are coordinated to palladium in reference complex $[3]\left(\mathbf{B F}_{4}\right)_{2}$. The coordination sphere of these three complexes was slightly distorted, as shown by the small dihedral angle in complexes
$[1] \mathrm{PF}_{6}\left(\mathrm{~N} 1-\mathrm{N} 2-\mathrm{C} 17-\mathrm{N} 4=3.96^{\circ}\right),[2] \mathrm{PF}_{6}(\mathrm{~N} 1-\mathrm{N} 2-\mathrm{N} 4-$ $\left.\mathrm{C} 22=2.91^{\circ}\right)$, and $[3]\left(\mathrm{BF}_{4}\right)_{2}\left(\mathrm{~N} 1-\mathrm{N} 2-\mathrm{N} 4-\mathrm{N} 5=5.42^{\circ}\right) \cdot \tau_{4}$, a structural parameter used to distinguish square-planar from tetrahedral coordination complexes $\left(\tau_{4}=360^{\circ}-(\alpha+\beta) /\right.$ $\left(141^{\circ}\right)$, where $\alpha$ and $\beta$ are the two greatest valence angles of the coordination sphere), ${ }^{45}$ was 0.112 for $[1] \mathbf{P F}_{6}, 0.109$ for [2] $\mathbf{P F}_{6}$, and 0.097 for $[3]\left(\mathbf{B F}_{4}\right)_{2}$, suggesting that these complexes are essentially square planar. The two cyclometalated, monocationic palladium complexes also showed clear $\pi-\pi^{*}$ stacking and short Pd-Pd distances (3.275-4.316 $\AA$ ), suggesting the occurrence of $\mathrm{Pd} \cdots \mathrm{Pd}$ metallophilic interaction. ${ }^{46}$ In contrast, reference complex $[3]\left(\mathrm{BF}_{4}\right)_{2}$ had higher Pd...Pd distances $(6.814-8.373 \AA$ A) that were almost twice as long, indicating the absence of $\mathrm{Pd} \cdots \mathrm{Pd}$ interaction in this bicationic compound (Figure 1b). Interestingly, these metal-metal interactions stimulate cyclometalated complexes $[1] \mathbf{P F}_{6}-[2] \mathbf{P F}_{6}$ to self-assemble. ${ }^{47-49}$ Overall, X-ray crystallography was consistent with NMR results and suggested that $\mathrm{Pd} \cdots \mathrm{Pd}$ metallophilic interaction may occur both in solution and in the solid state. 
Table 2. Photophysical Data for Complex $[1]$ OAc- $[3](\text { OAc })_{2}$

\begin{tabular}{|c|c|c|c|c|c|c|}
\hline \multirow[b]{2}{*}{ complex } & \multirow[b]{2}{*}{$\lambda_{\mathrm{abs}}, \mathrm{nm}\left(\varepsilon \times 10^{3} \mathrm{M}^{-1} \mathrm{~cm}^{-1}\right)^{a}$} & \multirow[b]{2}{*}{$\lambda_{\mathrm{em}}(\mathrm{nm})^{a}$} & \multirow[b]{2}{*}{$\varphi_{\mathrm{p}}$} & \multicolumn{2}{|c|}{ lifetime (ns) $)^{a, d}$} & \multirow[b]{2}{*}{$\varphi_{\Delta}{ }^{e}$} \\
\hline & & & & $\tau_{1}$ & $\tau_{2}$ & \\
\hline$[1] \mathrm{OAc}$ & $428(2.12), 455(1.50)$ & 593 & $0.0029^{b}$ & $0.159 \pm 0.003$ & & $0.78^{f}, 0.73^{8}$ \\
\hline$[2] \mathrm{OAc}$ & $344(6.10), 455(0.037)$ & 509 & $0.00038^{b}$ & $0.211 \pm 0.008$ & & $0.052^{f}$ \\
\hline$[3](\mathrm{OAc})_{2}$ & $364(7.45), 455(0.056)$ & 430 & $0.0038^{c}$ & $0.309 \pm 0.003(87 \%)$ & $4.17 \pm 0.08(13 \%)$ & $0.009^{f}$ \\
\hline
\end{tabular}

${ }^{a}$ Measurements were carried out in Milli-Q water. ${ }^{b}$ Phosphorescence quantum yield measurements of $[1]^{+}-[2]^{+}$were carried out at a $390 \mathrm{~nm}$ excitation wavelength in aerated water using $\left[\mathrm{Ru}(\mathrm{bpy})_{3}\right] \mathrm{Cl}_{2}\left(\varphi_{\mathrm{p}}=0.028\right)$ as the standard. ${ }^{50}{ }^{c}$ Phosphorescence quantum yield measurements of $[3]^{2+}$ were carried out at a $350 \mathrm{~nm}$ excitation wavelength in aerated ethanol using 9,10-diphenylanthracene $\left(\varphi_{\mathrm{p}}=0.885\right)$ as the standard. ${ }^{50}$ ${ }^{d}$ Excitation wavelength $375 \mathrm{~nm}$. ${ }^{e}$ Excitation wavelength $450 \mathrm{~nm}$, air atmosphere. The absorption of each complex at $450 \mathrm{~nm}$ was adjusted to 0.1 to avoid the generation of excimer. ${ }^{f}$ In $\mathrm{CD}_{3} \mathrm{OD}$ by spectroscopic detection at $1270 \mathrm{~nm}$; $\left[\mathrm{Ru}(\mathrm{bpy})_{3}\right] \mathrm{Cl}_{2}$ was used as the standard $\left(\varphi_{\Delta}=0.73\right) .{ }^{38} g_{\mathrm{In}}$ Opti-MEM complete using 9,10-anthracenediyl-bis(methylene)dimalonic acid as the ${ }^{1} \mathrm{O}_{2}$ probe; $\left[\mathrm{Ru}(\mathrm{bpy})_{3}\right] \mathrm{Cl}_{2}$ was used as the standard $\left(\varphi_{\Delta}=\right.$ 0.14 ; see the SI for details).

a

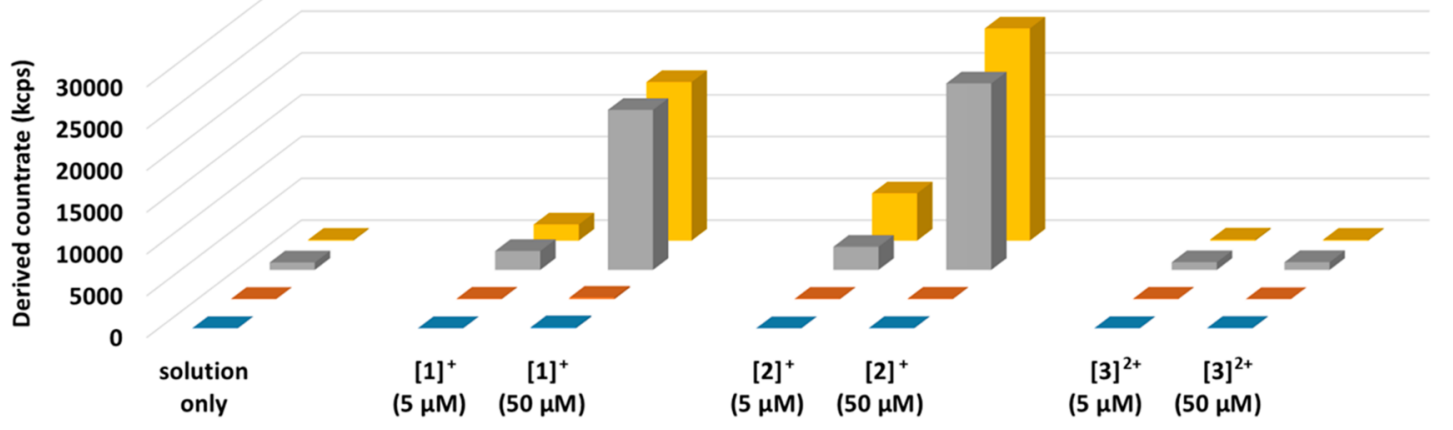

water $\quad$ PBS Opti-MEM with FCS $\quad$ Opti-MEM without FCS
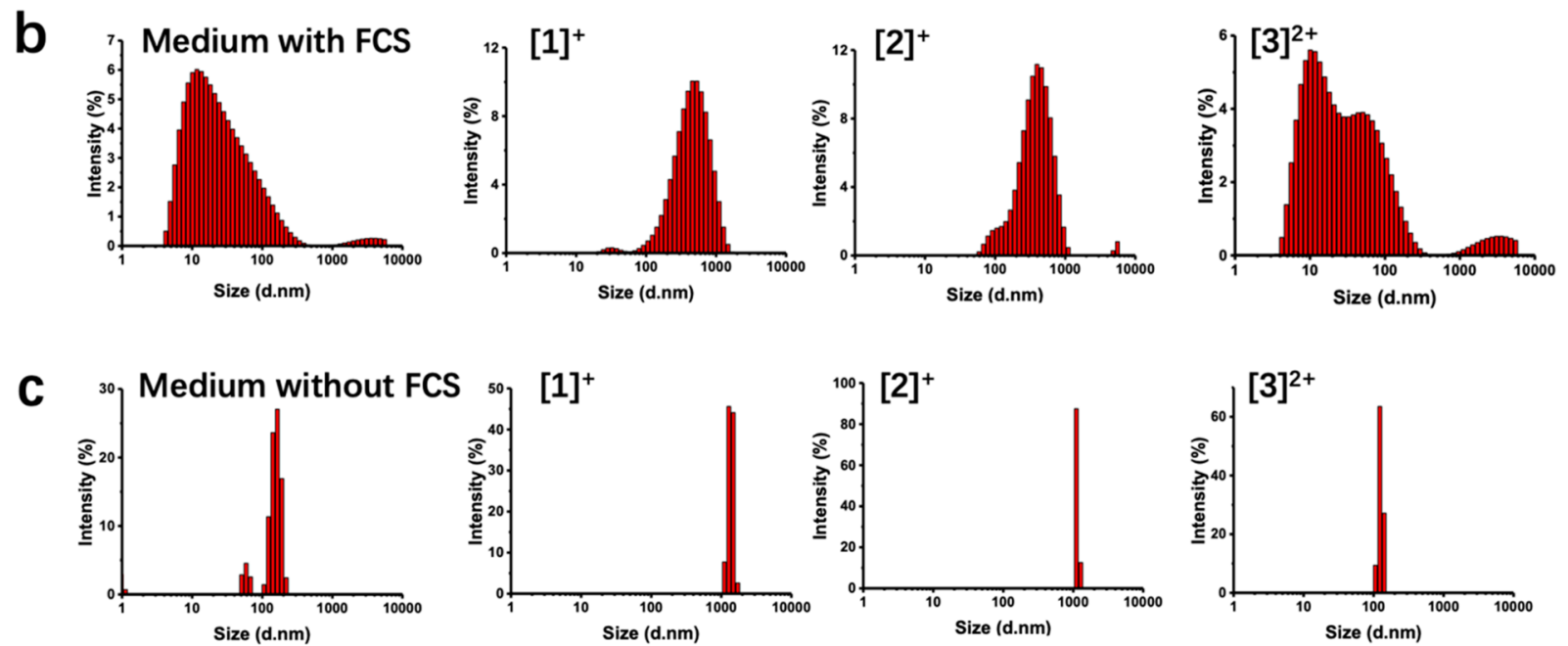

Figure 3. (a) Dynamic light scattering derived count rate of $[1]^{+}-[3]^{2+}$ at 5 or $50 \mu \mathrm{M}$ in pure water, PBS, and Opti-MEM medium with or without FCS $(2.5 \% \mathrm{v} / \mathrm{v})$. Size distribution of the DLS analysis of solutions of $[1]^{+}-[3]^{2+}(50 \mu \mathrm{M})$ in Opti-MEM medium with (b) or without (c) FCS. The $X$ axis is the hydrodynamic diameter (in $\mathrm{nm}$ ); the $Y$ axis is intensity (\%).

Photophysical Characterization and Frontier Orbitals. The photophysical properties of $[1] \mathrm{OAc}-[3](\mathrm{OAc})_{2}$ in water are shown in Figure 2 and Table 2. Importantly (see below) under such conditions none of the molecules aggregate. Complexes $[2]^{+}$and $[3]^{2+}$ showed intense absorbance essentially in the ultraviolet range (300-400 $\mathrm{nm}$ ), but a bathochromically shifted absorption band was observed for $[1]^{+}$, characterized by an absorption maximum at $428 \mathrm{~nm}$. As a result, in pure water the molar absorptivity values at $455 \mathrm{~nm}$ for the three complexes were 1500,37 , and $56 \mathrm{M}^{-1} \mathrm{~cm}^{-1}$, respectively, indicating that while $[2]^{+}$or $[3]^{2+}$ are bad blue light PDT sensitizers, $[\mathbf{1}]^{+}$may be good at it. The difference in blue light absorption can be explained by the different HOMO-LUMO orbital energy gaps of the three compounds. According to DFT at the PBE0/TZP/COSMO level (Figure S14, Table S2), the HOMO and LUMO orbitals of all three complexes have $\pi$ symmetry and have a very low (5.55\% for $[1]^{+}$) to zero (for $[2]^{+}$and $[3]^{2+}$ ) contribution of the palladium centers. The HOMO is centered on the noncoordinated amine bridge $\mathrm{NMe}$ of the ligand, and in the two cyclometalated complexes, its energy is strongly affected by how close the electron-rich $\mathrm{Pd}-\mathrm{C}^{-}$bond is to $\mathrm{NMe}\left(\mathrm{E}_{\mathrm{HOMO}}=\right.$ 
$-6.24 \mathrm{eV}$ for $[1]^{+},-6.58 \mathrm{eV}$ for $\left.[2]^{+}\right)$. On the other hand, the LUMO is based on the bipyridine fragment of the ligand, and its energy is hence essentially independent of the position of the electron-rich $\mathrm{Pd}-\mathrm{C}^{-}$bond $\left(E_{\mathrm{LUMO}}=-2.41 \mathrm{eV}\right.$ for $[1]^{+}$, $-2.46 \mathrm{eV}$ for $\left.[2]^{+}\right)$. For $[3]^{2+}$, the HOMO was slightly stabilized compared to that of $[2]^{+}$due to the more electronpoor nature of the tetrapyridyl ligand compared to its cyclometalated version (Table S2). The resulting HOMOLUMO energy gaps of the three complexes follow the series $[1]^{+}(3.83 \mathrm{eV}) \ll[2]^{+}(4.11 \mathrm{eV})<[3]^{2+}(4.13 \mathrm{eV})$, which explains the better absorption of $[1]^{+}$in the blue region of the spectrum. These results were confirmed by time-dependent density functional theory calculations (TDDFT, see Figure S15). Compounds $[1]^{+}-[3]^{2+}$ showed their lowest-energy transitions at 412, 368, and $369 \mathrm{~nm}$, respectively, and these lowest-energy transitions corresponded to 97.5, 95.2, and 98.1\%, respectively, for the HOMO $\rightarrow$ LUMO transition. The excited states of these complexes, which must be of triplet multiplicity considering the heavy nature of the palladium atom and the efficient formation of ${ }^{1} \mathrm{O}_{2}$ (see below), hence have intraligand charge transfer character $\left({ }^{3} \mathrm{ILCT}\right)$. The phosphorescence emission from these states was similarly weak and very short in aerated Milli-Q solutions (Figure 2a), with quantum yields $\left(\varphi_{\mathrm{p}}\right)$ lower than $0.5 \%$ and lifetimes of between 150 and 310 ps (Table 2, Figure S16). However, their quantum yields for ${ }^{1} \mathrm{O}_{2}$ generation $\left(\varphi_{\Delta}\right)$, which were measured under $450 \mathrm{~nm}$ excitation by direct detection of the $1274 \mathrm{~nm}$ infrared emission of ${ }^{1} \mathrm{O}_{2}$ in $\mathrm{CD}_{3} \mathrm{OD}$, were very different (Figure $2 \mathrm{~b}$, Table 2 ). $[\mathbf{1}]^{+}$showed the best ${ }^{1} \mathrm{O}_{2}$ quantum yield (0.78, compared to 0.73 for the reference $\left.\left[\mathrm{Ru}(\mathrm{bpy})_{3}\right] \mathrm{Cl}_{2}\right){ }^{37}$ followed by $[2]^{+}(0.052)$ and finally $[3]^{2+}(0.009)$. Overall, $[1]^{+}$shows excellent properties for blue-light PDT, including good light absorption around $450 \mathrm{~nm}$ and excellent ${ }^{1} \mathrm{O}_{2}$ generation efficiency in air, while $[2]^{+}$is only slightly better than $[3]^{2+}$, which has negligible photodynamic properties.

Aggregation of the Metal Complexes in Cell Culture Medium. In this family of palladium complexes, cyclometalation of bicationic complex $[3]^{2+}$ lowers its charge from +2 to +1 , which influences the supramolecular interaction of the metal complexes with itself and with other charged biomolecules. The NMR and crystallographic studies discussed above stimulated us to compare the behavior of complexes $[1]^{+}-[3]^{2+}$ at 5 or $50 \mu \mathrm{M}$ in a series of biomimetic solvents: $\mathrm{H}_{2} \mathrm{O}$, PBS, Opti-MEM cell medium with $2.5 \%$ fetal calf serum (FCS; this mixture is hereafter called Opti-MEM complete), and Opti-MEM without FCS. The formation of nanoaggregation in the biomimetic solvents was studied with dynamic light scattering (DLS). All three palladium complexes dissolved well in water and PBS solution, as shown by the low DLS-derived count rate (in $\mathrm{kcps}$ ), indicating that no aggregation occurred under these conditions (Figure 3a, Table S5). In contrast, in the present of Opti-MEM cell medium with or without FCS, cyclopalladated complexes $[\mathbf{1}]^{+}-[2]^{+}$definitely aggregated into particles, with a 35 -fold (5 $\mu \mathrm{M})$ or 102 -fold $(50 \mu \mathrm{M})$ increase in the derived count rate values. However, the derived count rate for $[3]^{2+}$ in all biomimetic solvents remained at a low level. The difference behavior of complexes $[1]^{+}-[3]^{2+}$ in Opti-MEM demonstrates the significant influence of cyclometalation and complex charge on the aggregation properties of these palladium complexes. In addition, the size of the aggregates made in the $[1]^{+}-[2]^{+}$in medium utterly depended on the presence of serum proteins (Figure 3b, Figure S17). In the medium with FCS, the particle distribution maxima were at 458 and $396 \mathrm{~nm}$ at $50 \mu \mathrm{M}$ concentration (Figure $3 \mathrm{~b}$ ). In the absence of FCS, microparticles (hydrodynamic diameter $>1000 \mathrm{~nm}$ ) were formed, resulting in precipitation (Figure 3c). Upon increasing the palladium complex concentration from 5 to $50 \mu \mathrm{M}$, the nanoparticles at around $10-100 \mathrm{~nm}$, which belong to the FCS proteins, almost disappeared and were replaced by micrometer-sized particles (Figure S17). For bicationic complex $[3]^{2+}$, no significant changes occurred in the DLS analysis when the concentration was varied from 5 to $50 \mu \mathrm{M}$ in all solutions, showing the absence of aggregation for this compound (Figure 3, Figure S17). Meanwhile, the acidic nature of cancer cells ${ }^{51}$ stimulated us to observe the aggregation behavior of [1] OAc in cell medium at different $\mathrm{pH}$ values (3.30-7.64). As shown in Figure S18, $[1]^{+}$still formed nanoaggregates $(100-1000 \mathrm{~nm})$ while the size distribution maximum slightly increased with $\mathrm{pH}$, suggesting possible aggregation of this compound in the more acidic environment of cancer cells or in the lysosome.

Another view of the chemical stability and aggregation behavior of these complexes in different media was provided by following in time the absorbance spectra of solutions of $[1]^{+}-[3]^{2+}$ in $\mathrm{H}_{2} \mathrm{O}, \mathrm{PBS}$, and Opti-MEM cell medium with or without FCS (Figure S19). All complexes were stable in water and PBS solutions for $24 \mathrm{~h}$, confirming that the tetradentate nature of the ligand prevents the coordination of water or chloride ligands to the metal center. In addition, the complexes were stable in the presence of GSH and ascorbic acid (Figure S19), showing that palladium(II) was not reduced under such conditions. In cell medium with FCS, $[1]^{+}-[2]^{+}$showed significant increases in the baseline absorbance over $24 \mathrm{~h}$, which can be attributed to increased scattering by the nanoparticles forming in solutions. ${ }^{52}$ In contrast, in the medium without FCS the absorbance decreased quickly during the first $15 \mathrm{~min}$ and remained essentially constant in a second step, which can be assigned to precipitation. For $[3]^{2+}$, the absorbance did not vary significantly in the medium without FCS, confirming the higher solubility of the bicationic complex. However, in FCS-containing medium a dramatic change was observed, characterized by an isosbestic point at $358 \mathrm{~nm}$, indicating a chemical reaction between $[3]^{2+}$ and one of the components of FCS. These results matched the observations made by DLS (i.e., $[\mathbf{1}]^{+}-[2]^{+}$precipitated in medium without FCS but generated $\sim 400 \mathrm{~nm}$ hydrodynamic diameter nanoparticles when FCS was added to the cell medium). This result suggests that the proteins present in FCS play a dramatic role in the aggregation state of cyclopalladated compounds $[1]^{+}-[2]^{+}$, while for tetrapyridyl complex $[3]^{2+}$ this role is much less pronounced. We can hence expect a different mechanism of cell uptake for monocationic complexes $[1]^{+}-[2]^{+}$compared with dicationic compound $[3]^{2+}$ because many cell uptake pathways, including endocytosis, depend on the size of drugs. ${ }^{53,54}$ In addition, the aggregation of $[\mathbf{1}]^{+}-[\mathbf{2}]^{+}$ in an FCS-containing medium suggests that upon injection into the bloodstream of a mammal these types of cyclometalated compounds may generate protein-caped nanoparticles, which may influence the tumor uptake and biological half-time of cyclometalated compounds compared to nonaggregated small molecules such as $[3]^{2+}$.

Supramolecular Polymerization of Cyclometalated Complexes. If the data above demonstrated that nanoaggregates were stabilized in FCS-containing medium, it was not clear yet as to whether the palladium complex or proteins 

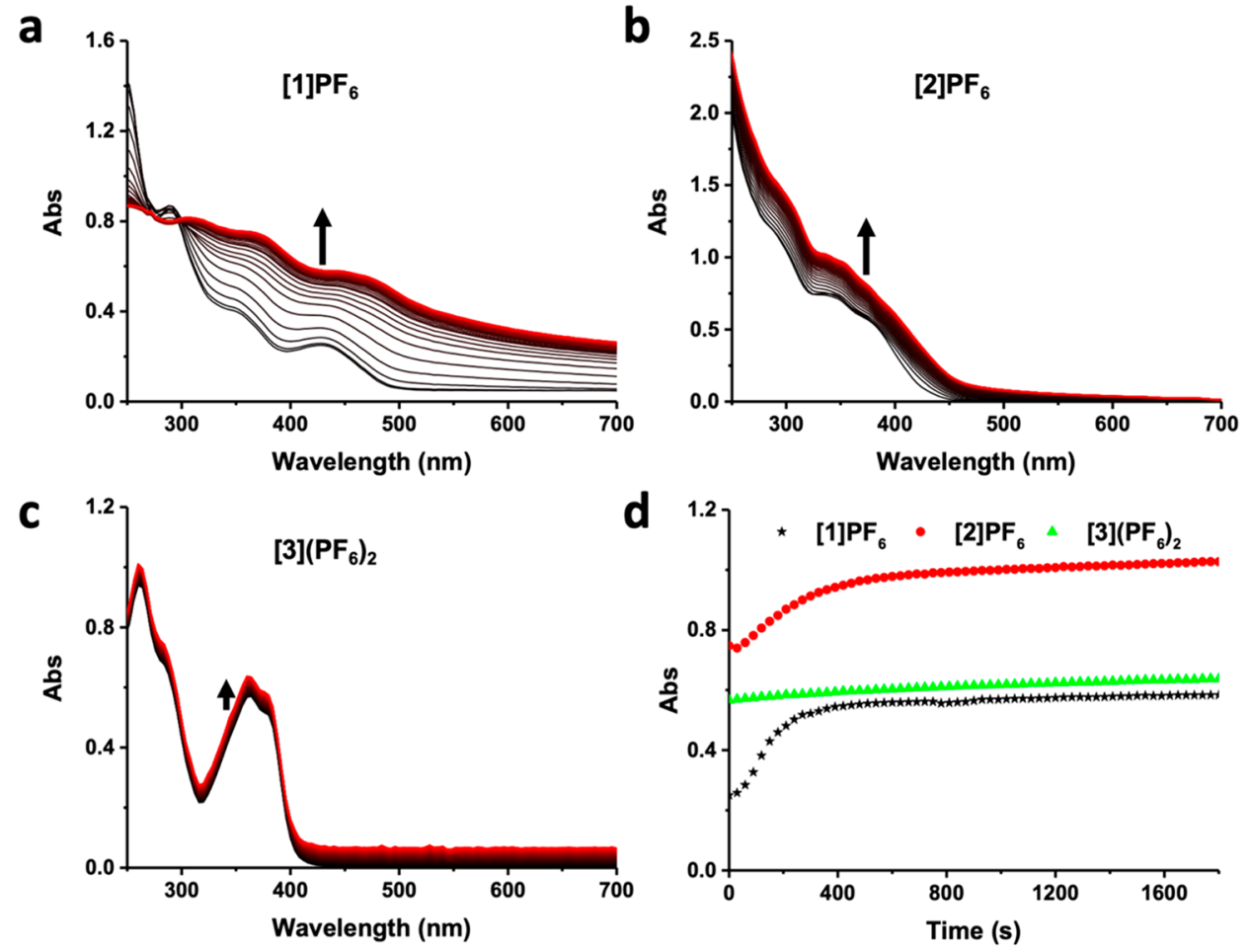

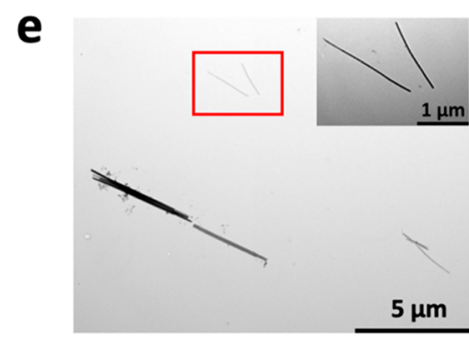

$[1] \mathrm{PF}_{6}$

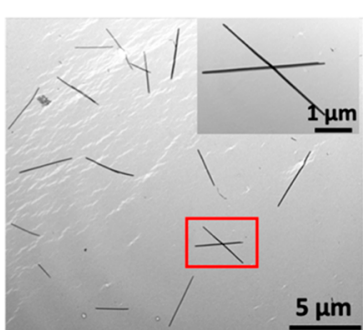

[2] $\mathrm{PF}_{6}$

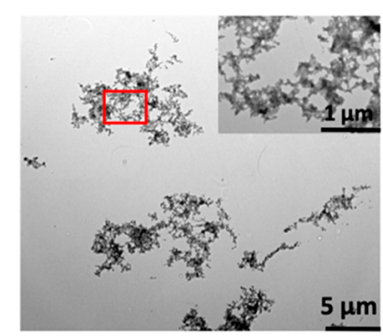

[3] $\left(\mathrm{PF}_{6}\right)_{2}$

Figure 4. Time evolution of the absorption spectra of the $\mathrm{H}_{2} \mathrm{O} / \mathrm{MeCN}$ solution $(100 \mu \mathrm{M}, 9: 1, \mathrm{v} / \mathrm{v})$ of complexes $[\mathbf{1}] \mathbf{P F}_{6}(\mathrm{a}),[\mathbf{2}] \mathbf{P F}_{6}(\mathrm{~b})$, and $[3]\left(\mathbf{P F}_{6}\right)_{2}(\mathrm{c})$ at $298 \mathrm{~K}$ for $30 \mathrm{~min}$. (d) Time evolution of the absorption at $428 \mathrm{~nm}$ (black stars, [1] $\left.\mathbf{P F}_{6}\right), 332 \mathrm{~nm}\left(\right.$ red dots, $\left.[2] \mathbf{P F}_{6}\right), 360 \mathrm{~nm}$ (green triangles, $\left.[\mathbf{3}]\left(\mathbf{P F}_{6}\right)_{2}\right)$ of these solutions. The absorption spectra were measured every $30 \mathrm{~s}$. (e) TEM images of $[\mathbf{1}] \mathbf{P F}_{6}(\mathrm{a}),[\mathbf{2}] \mathbf{P F _ { 6 }}(\mathrm{b})$, and $[3]\left(\mathrm{PF}_{6}\right)_{2}$ (c) after aggregation in the $\mathrm{H}_{2} \mathrm{O} / \mathrm{MeCN}$ solution $(100 \mu \mathrm{M}, 9: 1, \mathrm{v} / \mathrm{v})$ for $30 \mathrm{~min}$ (scale bar $5 \mu \mathrm{m}$, inset $\left.1 \mu \mathrm{m}\right)$.

abundant in serum, such as albumin, were responsible for aggregate formation. As $[1] \mathrm{OAc}-[3](\mathrm{OAc})_{2}$ do not form aggregates in pure water and form them too quickly in OptiMEM complete, we changed their counteranion to hexafluorophosphate by reprecipitation with $\mathrm{KPF}_{6}$ to make them less hydrophilic, which allowed for observing the kinetics of the formation of the nanorods. Supramolecular live polymerization of $[\mathbf{1}] \mathbf{P F}_{6}$ and $[2] \mathbf{P F}_{6}$ was observed in $\mathrm{H}_{2} \mathrm{O} / \mathrm{MeCN}$ solution $(100 \mu \mathrm{M}, 9: 1, \mathrm{v} / \mathrm{v})$ via $\mathrm{UV}$-vis absorption spectroscopy. ${ }^{48}$ As shown in Figure $4 a, b, d$, for $[\mathbf{1}] \mathbf{P F}_{6}$ and $[\mathbf{2}] \mathbf{P F}_{6}$ the baseline of the absorbance spectrum increased quickly (within 6 to 7 min), suggesting increasing light scattering; it then stabilized until the end of the experiment $(t=30 \mathrm{~min})$. By contrast, the absorbance of $[3]\left(\mathbf{P F}_{\mathbf{6}}\right)_{2}$ showed only negligible variations (Figure $4 c, d$ ). At the end of these UV-vis experiments, each solution was deposited on a TEM grid to observe the morphology of the nanoaggregates by TEM. Complexes $[1] \mathbf{P F}_{6}$ and $[2] \mathbf{P F}_{6}$ showed beautiful nanorod morphologies, while $[3]\left(\mathbf{P F}_{6}\right)_{2}$ showed random aggregates reminiscent of a precipitate. These data clearly show that cyclometalated complexes $[\mathbf{1}]^{+}-[2]^{+}$themselves are able to self-assemble into nanorods most probably due to the $\mathrm{Pd}$...Pd interaction observed in the solid state.

Cryo-TEM Measurements in Opti-MEM Medium. Compounds $[1]$ OAc- $[3](\mathbf{O A c})_{2}$ dissolve well in water with a low derived count rate according to DLS (Figure 3a). TEM gives a higher-contrast picture: while samples of [1] OAc[2] OAc prepared from a Milli-Q water solution $(50 \mu \mathrm{M})$ showed rectangular nanorods with an average length of around 139 and $203 \mathrm{~nm}$, respectively, samples of [3](OAc) ${ }_{2}$ at the same concentration showed random shapes characteristic of a precipitate (Figure S20). In both cases, the observed particulates were artifacts due to evaporation of the solvent prior to TEM imaging. Cryo-TEM, on the contrary, allows for observing nanostructures directly as they are in solution (i.e., in their native state). Cryo-TEM images of a $50 \mu \mathrm{M}$ solution of $[1] \mathrm{OAc}-[3](\mathrm{OAc})_{2}$ under different conditions were hence recorded. As shown in Figure 5 and Figure S21, the two cyclometalated compounds [1] OAc-[2] OAc in Opti-MEM did generate nanorods characterized by a width of $\sim 20 \mathrm{~nm}$. In the presence of FCS, these nanorods were nicely dispersed on the grid or were forming aggregates of about $500 \mathrm{~nm}$, while in the absence of FCS they aggregated in much larger 

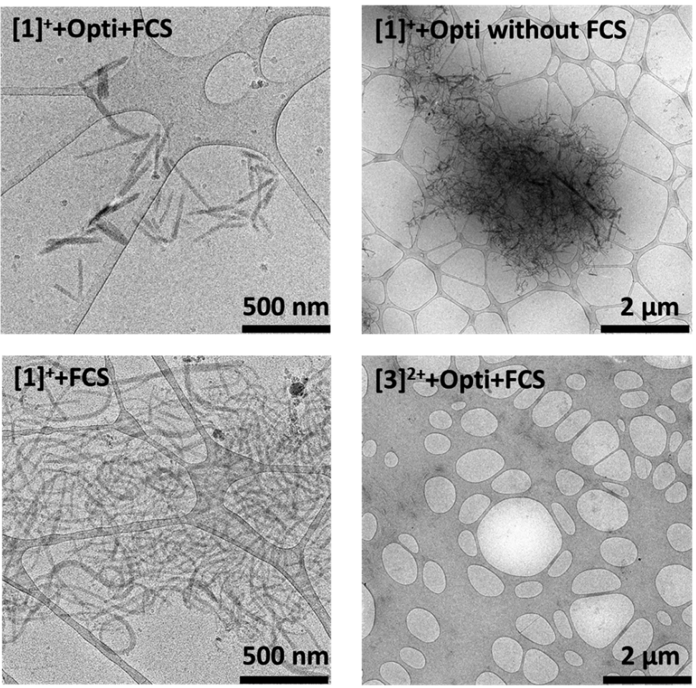

Figure 5. Cryo-TEM images of complexes $[1] \mathrm{OAc}$ and $[3](\mathrm{OAc})_{2}$ $(50 \mu \mathrm{M})$ in Opti-MEM medium with or without FCS or in pure FCS solution.

superaggregates of micrometer size. Compound [3](OAc) $)_{2}$, on the contrary, did not show such nanorods. Interestingly, when [1] OAc $(50 \mu \mathrm{M})$ was dispersed in pure FCS solution, bent nanofibers were observed, indicating that the proteins contained in FCS also played a role in the generation of nanostructures. Overall, all cryo-TEM images were fully consistent with the DLS results. From these data, it appears that FCS stabilized nanorods in the cell medium for cyclometalated compounds $[1]$ OAc $-[2]$ OAc while in the absence of FCS the nanorods aggregate with each other into larger clusters that end up precipitating out of solution.
Influence of the Charge on the Supramolecular Interaction. In order to understand why $[1]^{+}$and $[2]^{+}$selfassemble and not $[3]^{2+}$, we first minimized by DFT at the $\mathrm{PBE}$ /TZP/COSMO level in water a supramolecular dimer of $[\mathbf{1}]^{+}$and $[2]^{+}$(Figure S22, Table S6). Minimization converged with a local minimum characterized by $\mathrm{Pd}$..P distances of 3.18 and $3.20 \AA$, respectively, which qualitatively fits the experimental distance observed in the crystal structure (3.35 and $3.27 \AA$, respectively; see Figure 1b). This minimum demonstrates that for two isolated molecules of cyclometalated, monocationic complex $[1]^{+}$or $[2]^{+}$, electrostatic repulsion is low enough to be compensated for by the metallophilic Pd $\cdots \mathrm{Pd}$ interaction, coupled to $\pi-\pi$ stacking of the flat polyaromatic ligands. By contrast, a similar minimization run from a dimer of $[3]^{2+}$, assembled by hand at a short (3.18 $\AA$ ) Pd...Pd distance, saw the Pd...Pd distance increase steadily to $>6.5 \AA$ during energy minimization, without converging (data not shown). This result demonstrated that for $[3]^{2+}$ the charge and hence the intermolecular electrostatic repulsion are too high to be compensated for by the metallophilic interaction and the $\pi-\pi$ stacking that may occur at short Pd...Pd distances. Thus, the supramolecular assembly of $[\mathbf{1}]^{+}$and $[2]^{+}$seems to be modulated by the environment of the complex in solution (solvent, counteranions, and the presence of proteins), but it is an inherent property of these cyclometalated metal complexes. It originates from the strong and attractive combination between the metallophilic interaction and $\pi-\pi$ stacking between the ligands at short $\mathrm{Pd} \cdots \mathrm{Pd}$ distances, combined with low electrostatic repulsion. For $[3]^{2+}$, the latter is too strong to lead to supramolecular assembly.

Photophysical and Photochemical Properties of [1]OAc in Opti-MEM Complete Medium. As in a cell cytotoxicity assay, the cyclometalated complexes will be added
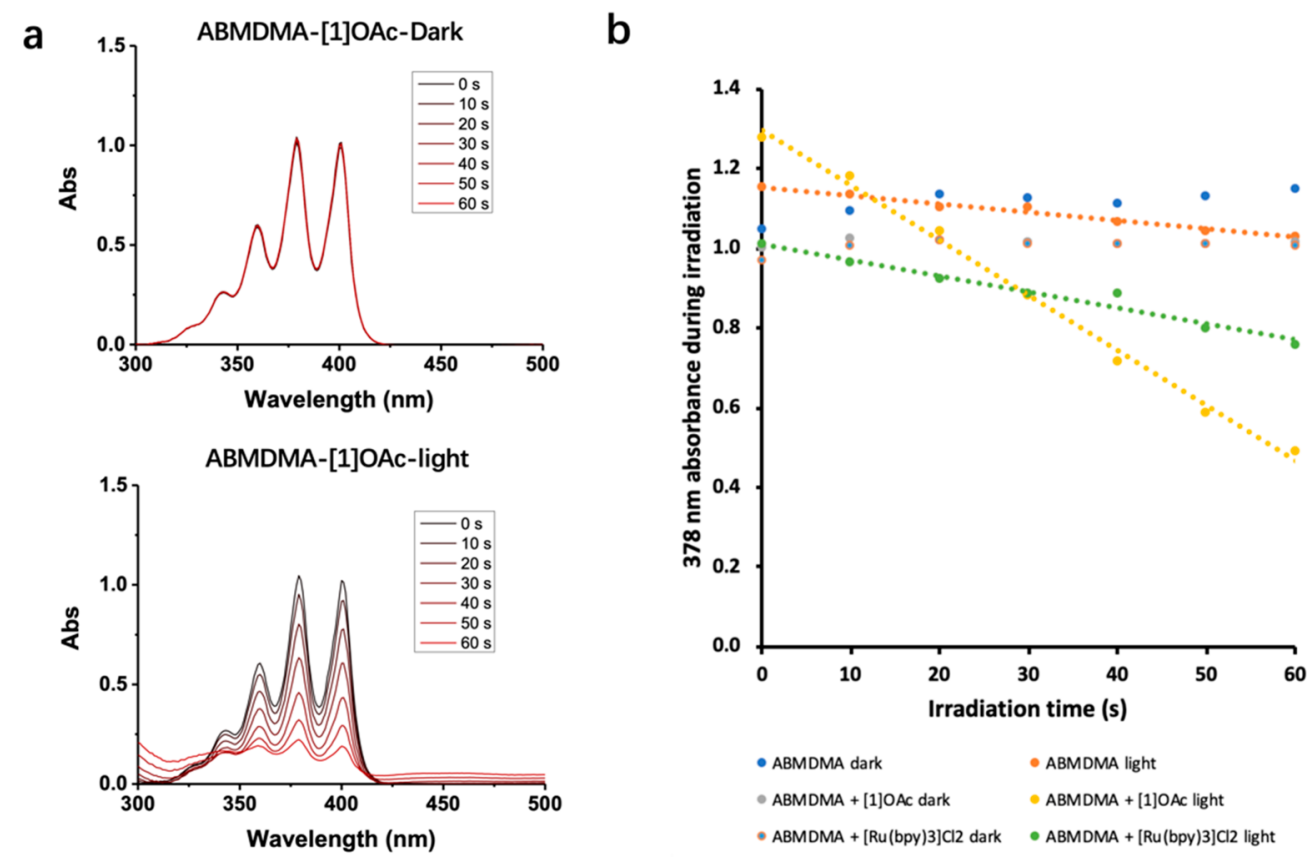

Figure 6. Singlet oxygen generation of aggregates of [1] OAc in Opti-MEM complete medium. (a) The absorbance change of ABMDMA (100 $\mu \mathrm{M})$ in Opti-MEM complete in the presence of [1] OAc $(50 \mu \mathrm{M})$ in the dark (top) or upon blue light irradiation (bottom). (b) Evolution of the absorbance at $378 \mathrm{~nm}$ vs irradiation time of ABMDMA $(100 \mu \mathrm{M})$ in Opti-MEM complete medium in the absence or presence of [1] OAc $(50 \mu \mathrm{M})$ or $\left[\mathrm{Ru}(\mathrm{bpy})_{3}\right] \mathrm{Cl}_{2}(50 \mu \mathrm{M})$ in the dark or under blue light irradiation. Irradiation conditions: $298 \mathrm{~K}, 450 \mathrm{~nm}, 5.23 \mathrm{~mW} \mathrm{~cm}$, and $1 \mathrm{~min}$. 
Table 3. Half-Maximal Effective Concentrations $\left(\mathrm{EC}_{50}\right.$ in $\left.\mu \mathrm{M}\right)$ of $[1]^{+}-[3]^{2+}$, Cisplatin, 5-ALA, and Rose Bengal for A549 and

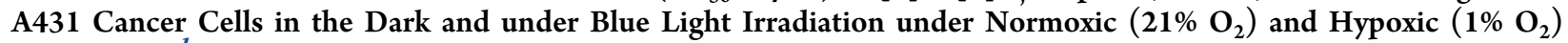
Conditions $^{a, b}$

\begin{tabular}{|c|c|c|c|c|c|c|c|c|c|}
\hline & & \multicolumn{8}{|c|}{$\mathrm{EC}_{50}(\mu \mathrm{M})$} \\
\hline & & \multicolumn{4}{|c|}{ normoxic condition } & \multicolumn{4}{|c|}{ hypoxic condition } \\
\hline \multicolumn{2}{|c|}{ complex } & A549 & $\pm \mathrm{CI}$ & A431 & $\pm \mathrm{CI}$ & A549 & $\pm \mathrm{CI}$ & A431 & $\pm \mathrm{CI}$ \\
\hline \multirow[t]{4}{*}[1]{$^{+}$} & dark & 2.2 & +0.4 & 45 & +13 & 6 & +3 & 100 & +70 \\
\hline & & & -0.4 & & -9 & & -2 & & -28 \\
\hline & light & 0.33 & +0.15 & 4.8 & +0.9 & 1.3 & +0.3 & 15 & +2 \\
\hline & & & -0.11 & & -0.8 & & -0.3 & & -2 \\
\hline PI & & 6.7 & & 9.4 & & 4.6 & & 6.7 & \\
\hline \multirow[t]{4}{*}[2]{$^{+}$} & dark & 2.7 & +0.7 & 12 & +4 & 4 & +1 & 29 & +38 \\
\hline & & & -0.6 & & -3 & & -1 & & -13 \\
\hline & light & 2.5 & +0.7 & 7 & +2 & 3 & 0.9 & 22 & +18 \\
\hline & & & -0.6 & & -1 & & -0.8 & & -8 \\
\hline PI & & 1.1 & & 1.4 & & 1.3 & & 1.3 & \\
\hline \multirow[t]{4}{*}[3]{$^{2+}$} & dark & 5 & +2 & 7 & +2 & 23 & +8 & 21 & +2 \\
\hline & & & -2 & & -2 & & -5 & & -1 \\
\hline & light & 4.4 & +0.9 & 6 & +1 & 15 & +4 & 21 & +3 \\
\hline & & & -0.9 & & -1 & & -3 & & -3 \\
\hline PI & & 1.1 & & 1.2 & & 1.5 & & 1.0 & \\
\hline \multirow[t]{4}{*}{ cisplatin } & dark & 3.1 & +0.6 & 2.5 & +0.4 & 24 & +11 & 13 & +4 \\
\hline & & & -0.5 & & -0.4 & & -5 & & -3 \\
\hline & light & 3.9 & +0.8 & 2.9 & +0.5 & 20 & +8 & 8 & +2 \\
\hline & & & -0.7 & & -0.4 & & -4 & & -2 \\
\hline PI & & 0.79 & & 0.86 & & 1.2 & & 1.6 & \\
\hline \multirow[t]{4}{*}{ 5-ALA } & dark & 390 & +620 & 11000 & +2200 & 13300 & +3400 & 16800 & +2800 \\
\hline & & & -270 & & -1900 & & -2700 & & -2400 \\
\hline & light & 170 & +250 & 1200 & +1900 & 14400 & +3500 & 19200 & +4500 \\
\hline & & & -110 & & -850 & & -2900 & & -3700 \\
\hline PI & & 2.3 & & 9.2 & & 0.9 & & 0.9 & \\
\hline \multirow[t]{4}{*}{ rose bengal } & dark & 63 & +13 & 57 & +28 & 76 & +18 & 70 & +22 \\
\hline & & & -11 & & -18 & & -16 & & -21 \\
\hline & light & 21 & +6 & 8 & +1 & 81 & +24 & 74 & +20 \\
\hline & & & -4 & & -1 & & -19 & & -19 \\
\hline PI & & 3.0 & & 7.1 & & 0.9 & & 0.9 & \\
\hline
\end{tabular}

${ }^{a}$ The $95 \%$ confidence interval $(\mathrm{CI}$ in $\mu \mathrm{M})$ and photoindexes $\left(\mathrm{PI}=\mathrm{EC}_{50, \text { dark }} / \mathrm{EC}_{50, \text { light }}\right)$ are also indicated. ${ }^{b}$ Irradiation condition: normoxic $455 \mathrm{~nm}$, $5 \mathrm{~min}, 5.66 \mathrm{~mW} \mathrm{~cm}^{-2}$, and $1.7 \mathrm{~J} \mathrm{~cm}^{-2}$; hypoxic $455 \mathrm{~nm}, 8 \mathrm{~min}, 3.54 \mathrm{~mW} \mathrm{~cm}^{-2}$, and $1.7 \mathrm{~J} \mathrm{~cm}^{-2}$. The data is the mean of three independent biological experiments.

in Opti-MEM complete medium and not in water or methanol, they will form aggregates rather than monomers. It is hence important to determine whether aggregation modifies the photophysical and photochemical properties of [1] OAc compared to the monomer. The absorbance (Figure S23a) of [1]OAc in medium, for example, showed on top of a broader and more intense absorption band between 350 and $500 \mathrm{~nm}$ a baseline increasing with decreasing wavelengths, which is typical for light scattering by nanoaggregates. Blue light absorption was improved for the aggregates compared to that for the monomer. The weak emission peak at $593 \mathrm{~nm}$ for [1] OAc in water (Figure S23b) was quenched in Opti-MEM complete medium and replaced by a new stronger peak with a maximum at $469 \mathrm{~nm}$. This new peak was located in a similar region compared to the emission peak of Opti-MEM complete medium itself, but it was more intense. The exact nature of the emitters responsible for this new band remains unknown; in particular, it is unclear whether this peak might be attributed to supramolecular associations between [1] OAc and endogenous fluorophores in the medium. All in all, the emission properties of the supramolecular aggregates of $[1]$ OAc were still too low to be observed in vitro by emission microscopy.
In terms of the ${ }^{1} \mathrm{O}_{2}$ generation quantum yield $\left(\varphi_{\Delta}\right)$, direct spectroscopic detection of the $1270 \mathrm{~nm}$ emission of ${ }^{1} \mathrm{O}_{2}$, which was used for determining $\varphi_{\Delta}$ of the monomer in $\mathrm{CD}_{3} \mathrm{OD}$, could not be used in a nondeuterated aqueous cell-growing medium, where the intensity of this NIR emission band was too low. Hence, to determine the value of $\varphi_{\Delta}$ of aggregates of [1] OAc in Opti-MEM medium, a specific water-soluble ${ }^{1} \mathrm{O}_{2}$ probe was used (i.e., 9,10-anthracenediyl-bis(methylene)dimalonic acid (ABMDMA)). In the dark, this dye absorbs light at around $378 \mathrm{~nm}$, but in the presence of photogenerated ${ }^{1} \mathrm{O}_{2}$, it forms an endoperoxide that leads to a loss of conjugation and thus a decrease in absorbance at $378 \mathrm{~nm} .{ }^{55}$ When [1] OAc $(50 \mu \mathrm{M})$ was mixed with ABMDMA $(100 \mu \mathrm{M})$ in Opti-MEM complete, the absorbance remained stable in the dark; however, upon $450 \mathrm{~nm}$ light irradiation the absorbance of ABMDMA dramatically decreased (Figure 6), showing the good ${ }^{1} \mathrm{O}_{2}$ production of the aggregates of [1] OAc. A high quantum yield of 0.73 was obtained by a quantitative comparison of the slope obtained with [1] OAc with the slope obtained with a reference sample of $\left[\mathrm{Ru}(\mathrm{bpy})_{3}\right] \mathrm{Cl}_{2}(50$ $\mu \mathrm{M}, \varphi_{\Delta, \text { ref }}=0.14$, see Figure S24 and details in the SI). ${ }^{56}$ Overall, [1] OAc retains excellent ${ }^{1} \mathrm{O}_{2}$ generation properties in 

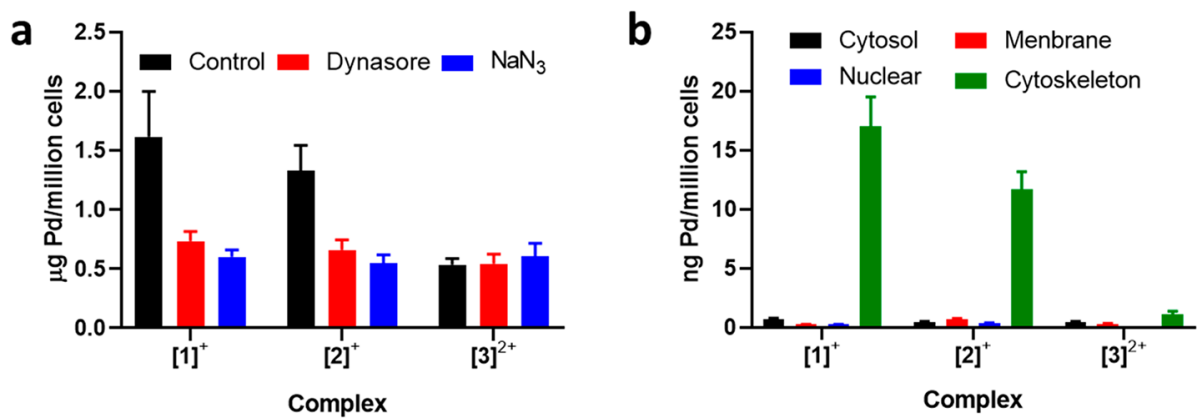

Figure 7. (a) Pd contents (expressed in $\mu \mathrm{g} \mathrm{Pd} /$ million cells) of A549 cells after treatment with $\mathrm{NaN}_{3}$ or dynasore for $1 \mathrm{~h}$ and compounds $[1]^{+}-$ $[3]^{2+}(5 \mu \mathrm{M})$ for $3 \mathrm{~h}$. (b) Distribution (expressed in $\mathrm{ng} \mathrm{Pd} /$ million cells) of palladium compounds $[1]^{+}-[3]^{2+}$ in the cytosol (black), membranes (red), nucleus (blue), and cytoskeleton (green) of A549 cells after treatment at $1 \mu \mathrm{M}$ for $24 \mathrm{~h}$.

the aggregated state and its blue light absorption properties are improved (i.e., its blue light PDT properties are improved in cell growing medium).

Phototoxicity Assay under Normoxic and Hypoxic Conditions. Considering the good photodynamic properties of $[1]^{+}$under blue light irradiation and its FCS-stabilized nanoaggregation behavior, the anticancer activities of $[1]^{+}-$ $[3]^{2+}$ were studied first in vitro, both in the dark and following a low dose of blue light $\left(1.7 \mathrm{~J} \mathrm{~cm}^{-2}\right)$. A dose-response curve was obtained in two human cancer cell lines A549 (lung cancer) and A431 (skin cancer) grown in 2D under normoxia $\left(21 \% \mathrm{O}_{2}\right)$ and using FCS-containing medium. The sulforhodamine B (SRB) assay was used as an end-point assay to quantify cell viability in treated vs untreated wells, and cisplatin was used as the positive control. The half-maximal effective concentrations $\left(\mathrm{EC}_{50}\right)$, defined as the compound concentration necessary to divide cell growth by a factor of 2 , compared to untreated wells, and the photoindexes (PI), defined as $\mathrm{EC}_{50 \text {,dark }} / \mathrm{EC}_{50 \text {,light }}$ are reported in Table 3. In A549, all three complexes showed significant anticancer abilities in the dark $\left(\mathrm{EC}_{50}<10 \mu \mathrm{M}\right)$, comparable to that of cisplatin, while in A431 $[3]^{2+}$ was much more toxic than $[1]^{+}-[2]^{+}$. This result suggests that the cyclopalladated complexes, unlike $[3]^{2+}$, might have a form of cell toxicity in the dark that is cellspecific. Upon blue light irradiation, complex $[\mathbf{1}]^{+}$showed a 6.7- and 9.4-fold increase in cytotoxicity toward A549 and A431 cancer cells, respectively, to reach $330 \mathrm{nM}$ cytotoxicity for A549 cells, which is 9.4 more toxic than cisplatin $(3.1 \mu \mathrm{M}$ in dark). These results are in line with the excellent singlet oxygen generation properties of this compound under blue light irradiation, and they were comparable, at such low doses of light $\left(<2 \mathrm{~J} . \mathrm{cm}^{-2}\right)$, to the photoindex obtained with the clinically approved 5-ALA control (PI $=9.8$ in normoxic A431 cells, see Table 3 ). Meanwhile, compounds $[2]^{+}-[3]^{2+}$ did not show any significant photocytotoxicity, which is consistent with their very low blue light absorption.

The excellent singlet oxygen generation properties of [1] OAc in both monomeric and aggregated forms and its clear blue light activation in normoxic cells suggested that this compound may work via a type II PDT mechanism (i.e., via energy transfer from the ${ }^{3} \mathrm{ILCT}$ states of the complex to ${ }^{3} \mathrm{O}_{2}$ ). When the cytotoxicity experiment was repeated in the same cancer cells grown under hypoxia $\left(1 \% \mathrm{O}_{2}\right.$, Figures S25-S27), the phototoxicity of $[\mathbf{1}]^{+}$indeed showed a 3 -fold decrease. However, it was not fully quenched because the photoindexes of 4.6 and 6.7 in A549 and A431, respectively, were smaller compared to 6.7 and 9.4 only under normoxia, respectively, but far from unity. By contrast, two well-known PDT type II photosensitizers, 5-ALA and rose bengal, when used as positive controls, showed a good PDT effect $(\mathrm{PI}<10)$ under normoxic conditions but no phototoxicity at all under hypoxic conditions, as expected for PDT type II photosensitizers. These results suggest that PDT type I may also occur with $[\mathbf{1}]^{+}$, as observed with other metal-based sensitizers. ${ }^{14}$ Finally, the higher $\mathrm{EC}_{50}$ obtained in the dark for $[1]^{+}-[3]^{2+}$ under hypoxic conditions can be rationalized by the different microenvironments and gene expression usually found in hypoxic cancer cells, which are known to overexpress resistance mechanisms compared to normoxic cells.

Cellular Uptake, Subcellular Fractionation, and Uptake Inhibition Studies with A549 Cells. Usually, nanoaggregates are taken up by endocytosis and end up either in the endosome or lysosome. ${ }^{57}$ In order to check this hypothesis, A549 cells were first treated for $1 \mathrm{~h}$ with sodium azide $(15.4 \mathrm{mM})$ or dynasore $(80 \mu \mathrm{M})$, which inhibited active uptake and dynamin-dependent endocytosis, respectively. ${ }^{58}$ Then, the cells were incubated with the three palladium complexes $(5 \mu \mathrm{M})$ for a short time (i.e., $3 \mathrm{~h})$. The Pd contents of the cells were finally determined by ICP-MS. As shown in Figure $7 \mathrm{a}$, in the control group without any inhibitors the drug uptake of cyclometalated compounds $[1]^{+}-[2]^{+}$was 3 times higher than that of tetrapyridyl analogue $[3]^{2+}$. In addition, samples pretreated with $\mathrm{NaN}_{3}$ or dynasore showed significant inhibition efficiency for the uptake of $[1]^{+}-[2]^{+}$, while no inhibition was observed for $[3]^{2+}$. These results clearly demonstrated that $[\mathbf{1}]^{+}-[\mathbf{2}]^{+}$were taken up in the cell via active, dynamin-dependent endocytosis, while $[3]^{2+}$ went into the cells by energy-independent uptake, possibly passive diffusion. This assay confirmed that $[1]^{+}-[2]^{+}$entered the cells as nanoaggregates and that cyclometalation dramatically changed the mechanism of cell uptake.

In a second experiment aimed at determining the intracellular localization, at longer incubation times for these nonemissive palladium complexes, A549 cells were treated with complexes [1] OAc-[3](OAc) ${ }_{2}(1 \mu \mathrm{M})$ for $24 \mathrm{~h}$ and then trypsinized and fractionated into four fractions: cytosol, membranes, nuclei, and cytoskeleton. The membrane fractions include not only the cell membrane but also the membranes in the mitochondria, endosomes, and lysosomes. In principle, nanoaggregates of $[1]^{+}-[2]^{+}$were expected to end up in the membrane fraction. The results (Figure $7 \mathrm{~b}$, Table S7) did not fit such expectations. $[1]^{+}-[2]^{+}$were found neither in the membrane nor in the nuclear fractions but almost exclusively ( 94.3 and $89.1 \%$, respectively) in the cytoskeleton fraction. In 
a

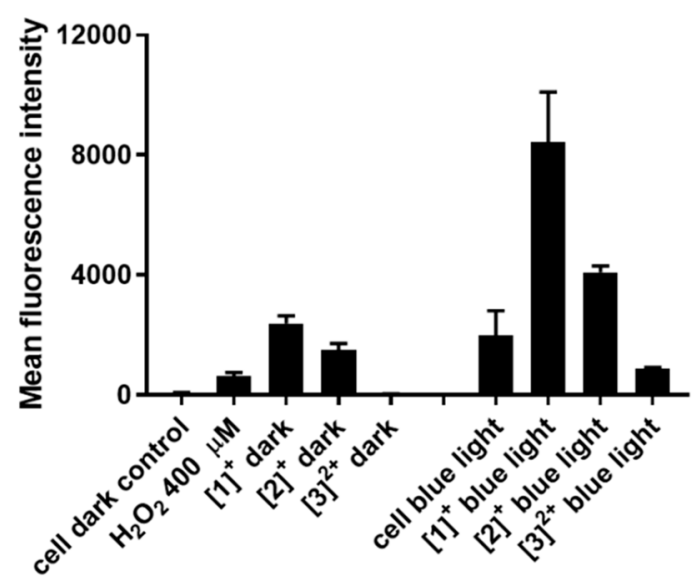

b

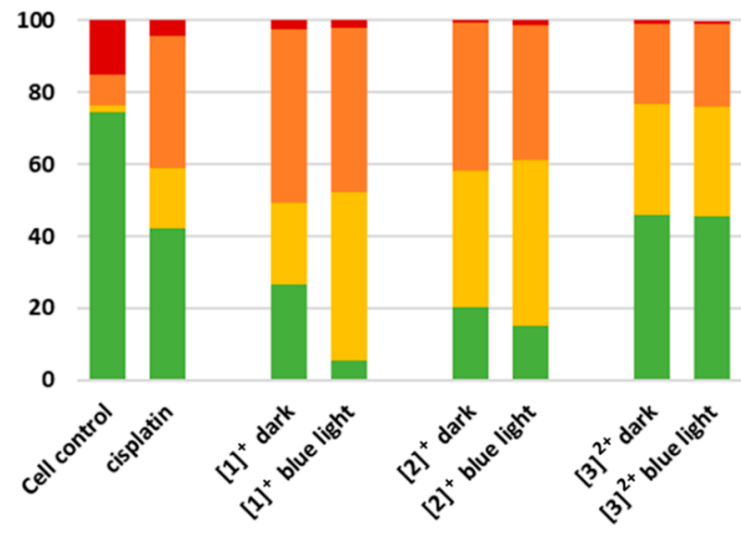

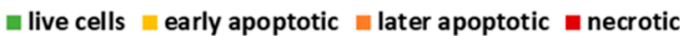

Figure 8. (a) Mean fluorescence intensity of cells treated first with [1] OAc-[3](OAc) $(5 \mu \mathrm{M}, 24 \mathrm{~h})$ and then with DCFDA $(20 \mu \mathrm{M}, 30 \mathrm{~min})$ and analyzed by flow cytometry. (b) Flow cytometry quantification of alive (Annexin -, PI -), early apoptotic (Annexin +, PI -), later apoptotic $\left(\right.$ Annexin,+ PI + ), and necrotic (Annexin -, PI +) A549 cells after treatment with $[1]^{+}-[3]^{2+}(15 \mu \mathrm{M})$ or cisplatin $(15 \mu \mathrm{M})$ in the dark or after irradiation for 5 min with blue light $\left(455 \mathrm{~nm}, 5.66 \mathrm{~mW} \mathrm{~cm}^{-2}, 1.7 \mathrm{~J} \mathrm{~cm}^{-2}\right)$.

contrast, [3] $]^{2+}$ was distributed among the cytoskeleton $(61.1 \%)$, the membrane fraction (15.5\%), and the cytosol (23.3\%). In addition, as at shorter times the total amount of palladium found in the cells was more than 10 times higher for cyclometalated complexes $[1]^{+}-[2]^{+}(19$ and $14 \mathrm{ng} \mathrm{Pd} /$ million cells, respectively) than for $[3]^{2+}(1.7 \mathrm{ng} \mathrm{Pd} /$ million cells). Overall, these combined ICP-MS results confirmed previous reports that cyclometalated compounds are more efficiently taken up than their polypyridyl analogue. However, they also shed new light on the reason for such enhanced uptake: considering their similar $\log P_{\text {ow }}$ values but very different aggregation behavior in the FCS-containing cell medium, it is the nanoaggregation of cyclometalated compounds $[1]^{+}-[2]^{+}$, stabilized by FCS, that leads to enhanced cellular uptake rather than passive uptake by diffusion through the cell membrane. In addition, the supramolecular nature of the interactions leading to aggregate formation seems weak enough to allow for a redistribution of the palladium complex after endocytosis, as palladium ends up in the cytoskeleton fraction rather than in the endosome or lysosome. According to this study, the mode of action of $[\mathbf{1}]^{+}-$ $[2]^{+}$is very unlikely to be related to nuclear DNA damage, suggesting that these compounds may overcome chemotherapy resistance originating from DNA damage repair.

Intracellular ROS Determination and Apoptosis. The generation of ROS in cancer cells usually induced cell death via apoptosis. ${ }^{59}$ 2,7-Dichlorodihydrofluorescein diacetate (DCFHDA) is an excellent sensor for intracellular ROS, which generates green-emissive metabolite $2^{\prime}, 7^{\prime}$-dichlorofluorescein (DCF). ROS levels were hence measured in A549 cells using flow cytometry after treatment with $[1]^{+}-[3]^{2+}(5 \mu \mathrm{M})$, followed or not by blue light irradiation $(455 \mathrm{~nm}, 5 \mathrm{~min}, 5.66$ $\mathrm{mW} \mathrm{cm}{ }^{-2}, 1.7 \mathrm{~J} \mathrm{~cm}^{-2}$; Figure $8 \mathrm{a}$ ). In the dark, cyclometalated complexes $[\mathbf{1}]^{+}-[\mathbf{2}]^{+}$showed significant ROS levels, even higher than that for the positive control $\left(400 \mu \mathrm{M} \mathrm{H}_{2} \mathrm{O}_{2}\right)$. Upon $455 \mathrm{~nm}$ irradiation, the ROS levels in all groups increased, especially for complex $[1]^{+}$, with a 3.5 -fold enhancement and the highest ROS level of all samples. This experiment confirmed the photodynamic character of lightinduced cell killing with $[\mathbf{1}]^{+}$. The ROS level found for $[\mathbf{2}]^{+}$ under blue light irradiation was close to the sum of the ROS levels found in cells treated with only blue light and that of cells treated with $[2]^{+}$and left in the dark, indicating the weak light-induced ROS generation ability of complex $[2]^{+}$. Unexpectedly, $[3]^{2+}$ inhibited ROS generation, compared with cells treated with $[3]^{2+}$ but kept in the dark or cells irradiated with blue light in the absence of any compound. The cytotoxicity difference between cyclometalated complexes $[1]^{+}-[2]^{+}$and $[3]^{2+}$ is the ability of the former to generate ROS in the dark and the ability of $[\mathbf{1}]^{+}$to absorb blue light to increase ROS generation.

The cell death mode triggered by such ROS formation in A549 cells was determined by flow cytometry using the Annexin V-FITC/propidium iodide double-staining assay (Figure S28). After $24 \mathrm{~h}$ of incubation with each complex, the A549 cells were irradiated with blue light or left in the dark and incubated for another $24 \mathrm{~h}$ and then harvested and treated with both dyes for FACS analysis. The percentage of live cells (Annexin -, PI -), early apoptotic (Annexin +, PI -), later apoptotic (Annexin +, PI +), and necrotic (Annexin -, PI +) cells are shown in Figure $8 \mathrm{~b}$. Clearly, in the dark $[1]^{+}-[3]^{2+}$ provoke cell death via apoptosis. Under blue light irradiation, the percentage of apoptotic cells induced by complex $[1]^{+}$ increased by $21 \%$ (from 71 to $92 \%$ ), while the other two complexes increased by only $4.3 \%\left([2]^{+}\right)$and $7.1 \%\left([3]^{2+}\right)$. Overall, in A549 cells [1 $]^{+}$kills cells via apoptosis in the dark by generating ROS near the cytoskeleton; this action is dramatically enhanced by low doses of blue light irradiation.

Photocytotoxicty of [1]OAc in Three-Dimensional Tumor Spheroids. In 2D cell monolayers, the physical access of the drug to the cancer cells is not an issue, and light optimally and equally bathes all cells, which represents a poor model of in vivo tumor treatment with PDT. By contrast, 3D multicellular tumor spheroid models provide a more accurate biological evaluation of the physical penetration of PDT drugs, nanoparticle-based drug delivery systems, and light. ${ }^{60}$ The cytotoxicity of $[\mathbf{1}]^{+}$in FCS-containing medium was hence tested in 3D tumor spheroids using a CellTiter-Glo 3D cell viability end-point assay to quantify the ATP concentration. ${ }^{41}$ As shown in Figure 9, it was possible to fully eradicate the tumor spheroids in the dark, suggesting that the nanoaggregates of $[\mathbf{1}]^{+}$and FCS either well penetrated the spheroid to kill simultaneously all cell layers including the center or destroyed the outer layers of the spheroids first to move 


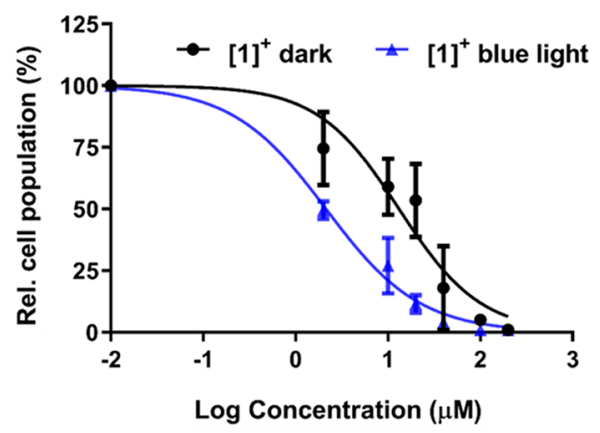

Figure 9. Dose-response curves for A549 3D tumor spheroids incubated with complex $[1]^{+}$irradiated for $10 \mathrm{~min}$ with blue light (in blue) or kept in the dark (in black). $\mathrm{EC}_{50 \text {,dark }}=13 \mu \mathrm{M}(95 \%$ confidence intervals $+7.7 \mu \mathrm{M},-6.0 \mu \mathrm{M}), \mathrm{EC}_{50, \text { light }}=2.1 \mu \mathrm{M}(95 \%$ confidence intervals $+0.7 \mu \mathrm{M},-0.7 \mu \mathrm{M})$, PI $=6.2$.

toward the center and kill the cells there. Upon blue light activation $\left(455 \mathrm{~nm}, 10 \mathrm{~min}, 3.48 \mathrm{~mW} \mathrm{~cm}^{-2}, 2.1 \mathrm{~J} \mathrm{~cm}^{-2}\right)$, the $\mathrm{EC}_{50}$ value of $3 \mathrm{D}$ tumor spheroids decreased by 6.2 -fold, from 13 to $2.1 \mu \mathrm{M}$, and here as well full eradication of ATP production could be achieved. Such a photoindex is surprisingly similar to the one measured in normoxic $2 \mathrm{D}$ cell monolayers (6.7), which again suggests that sensitizer penetration is not an issue here. These results not only confirm the excellent potential of $[\mathbf{1}]^{+}$as a blue light PDT agent but also highlight its ability to penetrate, as a nanoaggregate, to the core of tumor spheroids and to kill all cancer cells by a combination of a chemical (dark toxicity) and photochemical (blue-light activation) effect.

In Vivo Experiments. The penetration of blue light well matches the depth of skin cancers in the human body. Considering the excellent dark cytotoxicity of $[1]$ OAc in vitro and its good photodynamic properties in hypoxic cancer cells and 3D tumor spheroids, the in vivo antitumor property of compound [1] OAc was evaluated, in the dark or upon blue light irradiation $(450 \mathrm{~nm})$, in $4 \mathrm{~T} 1$ breast tumor xenografts in Balb/c female mice. This model is a commonly used subcutaneous tumor model in mice, which is better suited for blue light PDT in vivo than orthotopic xenografts models because of the short irradiation wavelength used. In general, intravenous tail injection is the main injection method for in vivo antitumor experiments because it best mimics the mode of administration of PDT sensitizers in clinical trials. However, in this work the higher dark cytotoxicity of the palladium complexes, compared to clinically approved PDT sensitizers, led us to consider paracancerous injection and a short drug-tolight interval of $1 \mathrm{~h}$ as a more efficient method for maximizing the drug concentration near the tumor and hence the PDT effect, while minimizing toxicity to the mice. Compound [2] OAc was also tested as a control complex that also forms nanoparticles in the presence of proteins, but does not absorb blue light at that wavelength. The mice $(N=3)$ were divided into six groups when the tumor volume reached around 40 $\mathrm{mm}^{3}$ : dark vehicle control, blue light-irradiated vehicle control, and injection of [1] OAc or [2] OAc $(40 \mu \mathrm{M}, 100 \mu \mathrm{L})$ either with or without blue light irradiation in a $60 \mathrm{~J} \mathrm{~cm}^{-2}$ light dose. The mice were treated twice, at days 0 and 2. One hour after compound injection, the mice were irradiated with blue light for $20 \mathrm{~min}$. The tumor volume of each mouse (Figure 10a) and the body weight (Figure S29) were measured and recorded over a period of 10 days following treatment. At day 10, the a
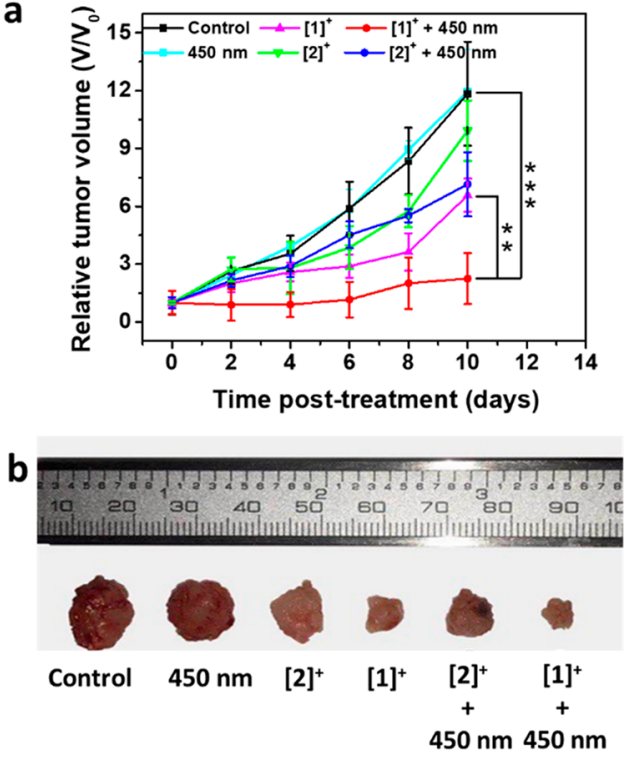

Figure 10. (a) Relative $4 \mathrm{~T} 1$ breast tumor volumes of $\mathrm{Balb} / \mathrm{c}$ mice and (b) visual tumor sizes at day 10 of Balb/c mice treated with vehicle control, $[\mathbf{1}]^{+}$, or $[2]^{+}$at day 0 and left in the dark or irradiated with blue light. Mice were treated on days 0 and 2 and irradiated with blue light $\left(450 \mathrm{~nm}, 50 \mathrm{~mW} \mathrm{~cm}{ }^{2}, 20 \mathrm{~min}, 60 \mathrm{~J} \mathrm{~cm}^{-2}\right) 1 \mathrm{~h}$ after injection. Statistical significance was set to $p<0.01(* *)$ and $0.001(* * *)$.

mice were sacrificed, and tumors were isolated to compare the volume scale of tumor spheres. All mice showed similar body weight at the end of the treatment (around $20 \mathrm{~g}$ ), meaning that the mice were healthy and the complexes were not very toxic to the mice itself. At day 10, the tumor of dark vehicle control and blue-light-irradiated vehicle control groups showed similar (and highest) volumes, followed by the mice group treated with $[2]^{+}($dark $)>[2]^{+}(450 \mathrm{~nm})>[1]^{+}($dark $)>[1]^{+}(450$ $\mathrm{nm}$ ). In the dark, the tumor volumes of mice were gradually growing with the treatment of complex $[1]^{+}$and $[2]^{+}$from day 0 to day 8 and then significantly increased on day 10 . When treated with $[1]^{+}$and irradiated with blue light on days 0 and 2 , no obvious growth of the tumor occurred over 10 days (Figure 10a), demonstrating the excellent photodynamic therapy properties of $[\mathbf{1}]^{+}$under these conditions.

As a side note, when the intravenous tail injection of a PDT sensitizer is chosen, longer drug-to-light intervals are typically used $(4-24 \mathrm{~h})$ in order to wait for the PDT sensitizer to accumulate in the tumor, in particular, for sensitizer nanoformulations relying on the enhanced permeability and retention (EPR) effect to enter the tumor. ${ }^{61}$ By contrast, paracancerous injection is a quicker and more direct method of concentrating the sensitizer (here the Pd nanoaggregates) near the tumor site. Also, it is better than intratumoral injection because paracancerous injection still holds the possibility of blood circulation of the drug to occur. On the other hand, a longer drug-to-light interval could lead to further transport of the drug to the rest of the body and unwanted toxicity to occur. Thus, a rather short drug-to-light time of $1 \mathrm{~h}$ was chosen. The final results suggest that $1 \mathrm{~h}$ is indeed a reasonable time setting and that under such conditions $[1]^{+}$penetrates well enough into the tumor to serve as a PDT sensitizer.

\section{DISCUSSION}

Traditionally, a vast majority of the PDT literature argues that because light penetration is better with red light than with blue 
light, blue light PDT is not relevant in vivo. Recently, however, research compared blue light vs red light for the 5aminolevulinic acid (ALA) photodynamic therapy of basal cell carcinoma patients. ${ }^{62,63}$ 5-ALA is transformed selectively by tumors into protoporphyrin IX, which can be excited either in the Soret band using blue light or in the $\mathrm{Q}$ band using red light. In this study, blue light showed statistically noninferior efficacy compared to red light, and a lower light fluence rate could be used with blue light due to the better light absorption of the Soret band, which generated less pain for the patients. ${ }^{62}$ These results suggested that blue light PDT should be studied and optimized further to evaluate its potential as an effective nonscarring anticancer treatment option in, for example, skin, eye, or bladder cancer. In cancers of superficial tissues indeed, short-wavelength (blue or green) PDT agents are interesting because short-wavelength light potentially reduces the damage to deeper healthy tissues. For skin cancer, for example, skin contains two layers: the cuticular layer $(\sim 0.08-0.27 \mathrm{~mm}$ thickness) and the derma ( 2.1-5.9 mm thickness).$^{64}$ As in skin tissue the penetration depth for blue, red, and NIR light is $1-2,4-5$, and $>5 \mathrm{~mm}$, respectively, ${ }^{65}$ blue light may reduce photodynamic damage to the derma. It is known that the cuticular tissue can recover soon after damage, but for the derma, tissue recovery is sometimes difficult. Thus, in the treatment of skin diseases, it is beneficial to reduce damage to the derma. Similar strategies are being developed in bladder cancer patients, where the green light PDT sensitizer (TLD1433) is currently in a clinical phase II trial ${ }^{13}$ to alleviate the phototoxicity issues experienced with red light PDT using photofrin in the end of the 1990s. ${ }^{66}$ Recently, Lilge's group reported a method to formulate TLD1433 with transferrin, which improved molar extinction coefficients in the visible domain of the spectrum, ROS production by the photosensitizer, cellular uptake, and the in vivo PDT efficacy. ${ }^{67}$ These results provide an inspiring example on how to further improve the photoactivity of cyclometalated PDT compounds such as $[\mathbf{1}]^{+}$.

In the present study, $[\mathbf{1}]^{+}$stands out for two reasons. First, it is an excellent singlet oxygen generator under blue light irradiation, while $[2]^{+}$and $[3]^{2+}$ have negligible absorption and singlet oxygen generation properties at such wavelengths. The bathochromically shifted absorbance of $[1]^{+}$is a consequence of the lower HOMO-LUMO gap in this compound due to (i) the presence and (ii) the position of the $\mathrm{Pd}-\mathrm{C}$ bond with respect to the noncoordinated amine bridge. ${ }^{36}$ The photodynamic properties of $[\mathbf{1}]^{+}$were observed in both normoxic and hypoxic $2 \mathrm{D}$ cell monolayers, suggesting that $[\mathbf{1}]^{+}$can serve for both PDT type II (normoxia) and type I (hypoxia). Second, the self-aggregation properties of $[1]^{+}$and $[2]^{+}$cause them to efficiently penetrate cancer cells via endocytosis where it is distributed to the cytoskeleton, while $[3]^{2+}$ is taken up in smaller amounts and is codistributed in the membranes and cytosol. These self-assembly properties are a direct consequence of the lower charge of the cyclometalated complexes, of their extended, flat aromatic ligand, of the presence of a palladium(II) atom in the center of the complexes, which generates Pd $\cdots$ Pd metallophilic interaction, ${ }^{49,68,69}$ and of the stabilization of the self-assembled nanorods in a biological medium by serum proteins. One should also note that although aggregation is often detrimental to the photodynamic properties of porphyrin sensitizers, for example, with cyclometalated palladium compounds such as $[1]^{+}$, self-assembly leads to nanostructures without quenching the blue-light photoreactivity. Of course, aggregation of the Pd complex as nanorods in the cell medium suggests that aggregation may also occur in the blood and that sensitizer uptake by the tumor may partially rely on the enhanced permeability and retention (EPR) effect via the trans-endothelial pathways. ${ }^{70}$ However, at that stage these hypotheses remain speculations. Altogether, the excellent uptake, localization, and photodynamic properties of $[\mathbf{1}]^{+}$make it an interesting blue-light-activated tumor killer not only in the $3 \mathrm{D}$ spheroid model but also in $4 \mathrm{~T} 1$ breast tumor xenografts in mice.

\section{CONCLUSIONS}

For metal-based anticancer drugs and photosensitizers, achieving cytotoxicity requires efficient cellular uptake. The most common method for increasing cellular uptake, which consists of increasing the lipophilicity of the compounds, allows for a better crossing of the lipophilic phospholipid bilayer of cells. Cyclometalation is one way to enhance the lipophilicity of metal complexes, and it almost systematically significantly improves cellular uptake. On the other hand, such a strategy is usually detrimental to the selectivity of the uptake because healthy cells also have a membrane. Our work offers a new perspective on the effects of cyclometalation on cell uptake beyond a simple increase in molecular lipophilicity. First, the octanol-water partition coefficient $(\log P)$ is always measured in the absence of serum protein, so similar $\log P$ values do not necessarily allow for predicting the solubility and aggregation properties of a drug candidate in cell growth medium or in blood. Second, when the balance between hydrophobicity and self-assembly properties is just right, cyclometalated complexes such as palladium complexes $[1]^{+}$ and $[2]^{+}$can generate nanoaggregates. Our results unambiguously demonstrate that the colloidal stability of these aggregates critically depends on the presence of the protein component (FCS) of the cell-growth medium and that in the presence of serum, cellular uptake in vitro is greatly enhanced compared to that of nonaggregated compounds such as $[3]^{2+}$. Endocytosis probably plays a critical role here; however, it should be noted that the compound was finally detected in the cytoskeleton rather than in the endosome or lysosome, which suggests that the supramolecular nature of the interaction responsible for the aggregation (i.e., $\mathrm{Pd} \cdots \mathrm{Pd}$ metallophilic interaction) may be reversible in the cell and allow for the compound to escape the endocytic pathway. Proteincontrolled self-assembly in aqueous solution via $\mathrm{Pd} \cdots \mathrm{Pd}$ metallophilic interaction has not been documented before. It suggests that (pro)drug self-assembly in serum may offer straightforward strategies for improving drug uptake without a sophisticated drug delivery system and that such strategies may work not only in vitro but also in vivo.

\section{ASSOCIATED CONTENT}

\section{Supporting Information}

The Supporting Information is available free of charge at https://pubs.acs.org/doi/10.1021/jacs.0c01369.

Synthesis details; NMR spectra; single-crystal crystallographic analysis; photophysical properties and phosphorescence lifetime spectra; dynamic light scattering data; singlet oxygen generation measurements; stability measurements of metal complexes in different environments; TEM images; computational details and calculated geometries of the dimers of $[1]^{+}$and $[2]^{+}$; 
cytotoxicity dose-response curves under normoxic and hypoxic conditions; uptake and subcellular fractionation studies; FACS data; and in vivo body weight analysis (PDF)

CIF file (CIF)

CIF file (CIF)

CheckCIF/PLATON report (PDF)

CIF file (CIF)

\section{AUTHOR INFORMATION}

\section{Corresponding Authors}

Wen Sun - State Key Laboratory of Fine Chemicals, Dalian University of Technology, Dalian 116024, China; (1) orcid.org/ 0000-0003-4316-5350; Email: sunwen@dlut.edu.cn

Sylvestre Bonnet - Leiden Institute of Chemistry, Universiteit Leiden, 2333, CC, Leiden, The Netherlands; (1) orcid.org/ 0000-0002-5810-3657; Email: bonnet@chem.leidenuniv.nl

\section{Authors}

Xue-Quan Zhou - Leiden Institute of Chemistry, Universiteit Leiden, 2333, CC, Leiden, The Netherlands

Ming Xiao - State Key Laboratory of Fine Chemicals, Dalian University of Technology, Dalian 116024, China

Vadde Ramu - Leiden Institute of Chemistry, Universiteit Leiden, 2333, CC, Leiden, The Netherlands

Jonathan Hilgendorf - Leiden Institute of Chemistry, Universiteit Leiden, 2333, CC, Leiden, The Netherlands

Xuezhao Li - State Key Laboratory of Fine Chemicals, Dalian University of Technology, Dalian 116024, China

Panagiota Papadopoulou - Leiden Institute of Chemistry, Universiteit Leiden, 2333, CC, Leiden, The Netherlands

Maxime A. Siegler - Department of Chemistry, Johns Hopkins University, Baltimore, Maryland 21218, United States

Alexander Kros - Leiden Institute of Chemistry, Universiteit Leiden, 2333, CC, Leiden, The Netherlands; (1) orcid.org/ 0000-0002-3983-3048

Complete contact information is available at:

https://pubs.acs.org/10.1021/jacs.0c01369

\section{Notes}

The authors declare no competing financial interest.

\section{ACKNOWLEDGMENTS}

X.-Q Zhou gratefully acknowledges the China Scholarship Council (CSC) for a personal grant (No. 201606200045). This work is supported by the European Research Council via a Starting Grant to S. Bonnet, National Natural Science Foundation of China (21808028) to W. Sun, and Huygens Fellowship Leiden University Grant to P. Papadopoulou. Prof. E. Bouwman is wholeheartedly acknowledged for scientific discussion and support. The Cryo-EM measurements benefited from access to The Netherlands Centre for Electron Nanoscopy (NeCEN) at Leiden University.

\section{REFERENCES}

(1) Štarha, P.; Vančo, J.; Trávníček, Z. Platinum iodido complexes: A comprehensive overview of anticancer activity and mechanisms of action. Coord. Chem. Rev. 2019, 380, 103-135.

(2) Dilruba, S.; Kalayda, G. V. Platinum-based drugs: past, present and future. Cancer Chemother. Pharmacol. 2016, 77 (6), 1103-24.

(3) Wang, X.; Guo, Z. Targeting and delivery of platinum-based anticancer drugs. Chem. Soc. Rev. 2013, 42 (1), 202-24.
(4) Browning, R. J.; Reardon, P. J. T.; Parhizkar, M.; Pedley, R. B.; Edirisinghe, M.; Knowles, J. C.; Stride, E. Drug Delivery Strategies for Platinum-Based Chemotherapy. ACS Nano 2017, 11 (9), 8560-8578.

(5) Dasari, S.; Tchounwou, P. B. Cisplatin in cancer therapy: molecular mechanisms of action. Eur. J. Pharmacol. 2014, 740, 364378

(6) Li, B.; Meng, Z.; Li, Q.; Huang, X.; Kang, Z.; Dong, H.; Chen, J.; Sun, J.; Dong, Y.; Li, J.; Jia, X.; Sessler, J. L.; Meng, Q.; Li, C. A pH responsive complexation-based drug delivery system for oxaliplatin. Chemical Science 2017, 8 (6), 4458-4464.

(7) Lovejoy, K. S.; Lippard, S. J. Non-traditional platinum compounds for improved accumulation, oral bioavailability, and tumor targeting. Dalton Transactions 2009, 48, 10651-10659.

(8) Petruzzella, E.; Sirota, R.; Solazzo, I.; Gandin, V.; Gibson, D. Triple action $\mathrm{Pt}(\mathrm{iv})$ derivatives of cisplatin: a new class of potent anticancer agents that overcome resistance. Chemical Science 2018, 9 (18), 4299-4307.

(9) Oun, R.; Moussa, Y. E.; Wheate, N. J. The side effects of platinum-based chemotherapy drugs: a review for chemists. Dalton Transactions 2018, 47 (19), 6645-6653.

(10) Galluzzi, L.; Senovilla, L.; Vitale, I.; Michels, J.; Martins, I.; Kepp, O.; Castedo, M.; Kroemer, G. Molecular mechanisms of cisplatin resistance. Oncogene 2012, 31 (15), 1869-83.

(11) Liu, J. N.; Bu, W.; Shi, J. Chemical Design and Synthesis of Functionalized Probes for Imaging and Treating Tumor Hypoxia. Chem. Rev. 2017, 117 (9), 6160-6224.

(12) Mallidi, S.; Anbil, S.; Bulin, A. L.; Obaid, G.; Ichikawa, M.; Hasan, T. Beyond the Barriers of Light Penetration: Strategies, Perspectives and Possibilities for Photodynamic Therapy. Theranostics 2016, 6 (13), 2458-2487.

(13) Monro, S.; Colon, K. L.; Yin, H.; Roque, J., 3rd; Konda, P.; Gujar, S.; Thummel, R. P.; Lilge, L.; Cameron, C. G.; McFarland, S. A. Transition Metal Complexes and Photodynamic Therapy from a Tumor-Centered Approach: Challenges, Opportunities, and Highlights from the Development of TLD1433. Chem. Rev. 2019, 119 (2), $797-828$.

(14) Castano, A. P.; Demidova, T. N.; Hamblin, M. R. Mechanisms in photodynamic therapy: part one-photosensitizers, photochemistry and cellular localization. Photodiagn. Photodyn. Ther. 2004, 1 (4), 279-293.

(15) Agostinis, P.; Berg, K.; Cengel, K. A.; Foster, T. H.; Girotti, A. W.; Gollnick, S. O.; Hahn, S. M.; Hamblin, M. R.; Juzeniene, A.; Kessel, D.; Korbelik, M.; Moan, J.; Mroz, P.; Nowis, D.; Piette, J.; Wilson, B. C.; Golab, J. Photodynamic therapy of cancer: an update. Ca-Cancer J. Clin. 2011, 61 (4), 250-81.

(16) He, T.; Ren, C.; Luo, Y.; Wang, Q.; Li, J.; Lin, X.; Ye, C.; Hu, W.; Zhang, J. Water-soluble chiral tetrazine derivatives: towards the application of circularly polarized luminescence from upper-excited states to photodynamic therapy. Chemical Science 2019, 10 (15), $4163-4168$

(17) Lam, T. L.; Tong, K. C.; Yang, C.; Kwong, W. L.; Guan, X.; Li, M. D.; Kar-Yan Lo, V.; Lai-Fung Chan, S.; Lee Phillips, D.; Lok, C. N.; Che, C. M. Luminescent ruffled iridium(iii) porphyrin complexes containing N-heterocyclic carbene ligands: structures, spectroscopies and potent antitumor activities under dark and light irradiation conditions. Chemical Science 2019, 10 (1), 293-309.

(18) Dong, Z.; Feng, L.; Hao, Y.; Chen, M.; Gao, M.; Chao, Y.; Zhao, H.; Zhu, W.; Liu, J.; Liang, C.; Zhang, Q.; Liu, Z. Synthesis of Hollow Biomineralized CaCO3-Polydopamine Nanoparticles for Multimodal Imaging-Guided Cancer Photodynamic Therapy with Reduced Skin Photosensitivity. J. Am. Chem. Soc. 2018, 140 (6), 2165-2178.

(19) Lv, Z.; Wei, H.; Li, Q.; Su, X.; Liu, S.; Zhang, K. Y.; Lv, W.; Zhao, Q.; Li, X.; Huang, W. Achieving efficient photodynamic therapy under both normoxia and hypoxia using cyclometalated $\mathrm{Ru}(\mathrm{ii})$ photosensitizer through type I photochemical process. Chemical Science 2018, 9 (2), 502-512.

(20) Huang, H.; Zhang, P.; Chen, H.; Ji, L.; Chao, H. Comparison between polypyridyl and cyclometalated ruthenium(II) complexes: 
anticancer activities against 2D and 3D cancer models. Chem. - Eur. J. 2015, 21 (2), 715-25.

(21) Heinemann, F.; Karges, J.; Gasser, G. Critical Overview of the Use of $\mathrm{Ru}(\mathrm{II})$ Polypyridyl Complexes as Photosensitizers in OnePhoton and Two-Photon Photodynamic Therapy. Acc. Chem. Res. 2017, 50 (11), 2727-2736.

(22) Salassa, L. Polypyridyl Metal Complexes with Biological Activity. Eur. J. Inorg. Chem. 2011, 2011 (32), 4931-4947.

(23) Arora, K.; Herroon, M.; Al-Afyouni, M. H.; Toupin, N. P.; Rohrabaugh, T. N.; Loftus, L. M.; Podgorski, I.; Turro, C.; Kodanko, J. J. Catch and Release Photosensitizers: Combining Dual-Action Ruthenium Complexes with Protease Inactivation for Targeting Invasive Cancers. J. Am. Chem. Soc. 2018, 140 (43), 14367-14380.

(24) Whittemore, T. J.; Millet, A.; Sayre, H. J.; Xue, C.; Dolinar, B. S.; White, E. G.; Dunbar, K. R.; Turro, C. Tunable Rh2(II,II) Light Absorbers as Excited-State Electron Donors and Acceptors Accessible with Red/Near-Infrared Irradiation. J. Am. Chem. Soc. 2018, 140 (15), 5161-5170.

(25) Clement, M.; Daniel, G.; Trelles, M. Optimising the design of a broad-band light source for the treatment of skin. J. Cosmet. Laser Ther. 2005, 7 (3-4), 177-89.

(26) Ghosh, G.; Colon, K. L.; Fuller, A.; Sainuddin, T.; Bradner, E.; McCain, J.; Monro, S. M. A.; Yin, H.; Hetu, M. W.; Cameron, C. G.; McFarland, S. A. Cyclometalated Ruthenium(II) Complexes Derived from alpha-Oligothiophenes as Highly Selective Cytotoxic or Photocytotoxic Agents. Inorg. Chem. 2018, 57 (13), 7694-7712.

(27) Notaro, A.; Gasser, G.; Castonguay, A. Note of Caution for the Aqueous Behaviour of Metal-Based Drug Candidates. ChemMedChem 2020, 15 (4), 345-348.

(28) Tsai, J. L.; Zou, T.; Liu, J.; Chen, T.; Chan, A. O.; Yang, C.; Lok, C. N.; Che, C. M. Luminescent platinum(ii) complexes with selfassembly and anti-cancer properties: hydrogel, $\mathrm{pH}$ dependent emission color and sustained-release properties under physiological conditions. Chemical Science 2015, 6 (7), 3823-3830.

(29) Suntharalingam, K.; Wilson, J. J.; Lin, W.; Lippard, S. J. A dualtargeting, p53-independent, apoptosis-inducing platinum(II) anticancer complex, $[\mathrm{Pt}(\mathrm{BDI}(\mathrm{QQ}))] \mathrm{Cl}$. Metallomics 2014, 6 (3), 43743.

(30) Wragg, A.; Gill, M. R.; McKenzie, L.; Glover, C.; Mowll, R.; Weinstein, J. A.; Su, X.; Smythe, C.; Thomas, J. A. Serum Albumin Binding Inhibits Nuclear Uptake of Luminescent Metal-ComplexBased DNA Imaging Probes. Chem. - Eur. J. 2015, 21 (33), 1186571.

(31) Lok, C. N.; Zou, T.; Zhang, J. J.; Lin, I. W.; Che, C. M. Controlled-release systems for metal-based nanomedicine: encapsulated/self-assembled nanoparticles of anticancer gold(III)/platinum(II) complexes and antimicrobial silver nanoparticles. Adv. Mater. 2014, 26 (31), 5550-7.

(32) Qiu, K.; Chen, Y.; Rees, T. W.; Ji, L.; Chao, H. Organelletargeting metal complexes: From molecular design to bio-applications. Coord. Chem. Rev. 2019, 378, 66-86.

(33) Wu, P.; Wong, E. L.; Ma, D. L.; Tong, G. S.; Ng, K. M.; Che, C. M. Cyclometalated platinum(II) complexes as highly sensitive luminescent switch-on probes for practical application in protein staining and cell imaging. Chem. - Eur. J. 2009, 15 (15), 3652-6.

(34) Shang, L.; Nienhaus, K.; Nienhaus, G. U. Engineered nanoparticles interacting with cells: size matter. J. Nanobiotechnol. 2014, 12,5 .

(35) Azzouzi, A.-R.; Vincendeau, S.; Barret, E.; Cicco, A.; Kleinclauss, F.; van der Poel, H. G.; Stief, C. G.; Rassweiler, J.; Salomon, G.; Solsona, E.; Alcaraz, A.; Tammela, T. T.; Rosario, D. J.; Gomez-Veiga, F.; Ahlgren, G.; Benzaghou, F.; Gaillac, B.; Amzal, B.; Debruyne, F. M. J.; Fromont, G.; Gratzke, C.; Emberton, M. Padeliporfin vascular-targeted photodynamic therapy versus active surveillance in men with low-risk prostate cancer (CLIN1001 PCM301): an open-label, phase 3, randomised controlled trial. Lancet Oncol. 2017, 18 (2), 181-191.

(36) Zhou, X. Q.; Busemann, A.; Meijer, M. S.; Siegler, M. A.; Bonnet, $\mathrm{S}$. The two isomers of a cyclometallated palladium sensitizer show different photodynamic properties in cancer cells. Chem. Commun. 2019, 55 (32), 4695-4698.

(37) DeRosa, M. C.; Crutchley, R. J. Photosensitized singlet oxygen and its applications. Coord. Chem. Rev. 2002, 233-234, 351-371.

(38) Cuello-Garibo, J. A.; Meijer, M. S.; Bonnet, S. To cage or to be caged? The cytotoxic species in ruthenium-based photoactivated chemotherapy is not always the metal. Chem. Commun. 2017, 53 (50), $6768-6771$.

(39) Hopkins, S. L.; Siewert, B.; Askes, S. H.; Veldhuizen, P.; Zwier, R.; Heger, M.; Bonnet, S. An in vitro cell irradiation protocol for testing photopharmaceuticals and the effect of blue, green, and red light on human cancer cell lines. Photochemical and Photobiological Sciences 2016, 15 (5), 644-53.

(40) Vichai, V.; Kirtikara, K. Sulforhodamine B colorimetric assay for cytotoxicity screening. Nat. Protoc. 2006, 1 (3), 1112-6.

(41) Zanoni, M.; Piccinini, F.; Arienti, C.; Zamagni, A.; Santi, S.; Polico, R.; Bevilacqua, A.; Tesei, A. 3D tumor spheroid models for in vitro therapeutic screening: a systematic approach to enhance the biological relevance of data obtained. Sci. Rep. 2016, 6, 19103.

(42) Sun, W.; Fan, J.; Wang, S.; Kang, Y.; Du, J.; Peng, X. Biodegradable Drug-Loaded Hydroxyapatite Nanotherapeutic Agent for Targeted Drug Release in Tumors. ACS Appl. Mater. Interfaces 2018, 10 (9), 7832-7840.

(43) Chan, K. T.; Tong, G. S. M.; Wan, Q.; Cheng, G.; Yang, C.; Che, C. M. Strongly Luminescent Cyclometalated Gold(III) Complexes Supported by Bidentate Ligands Displaying Intermolecular Interactions and Tunable Emission Energy. Chem. - Asian J. 2017, 12 (16), 2104-2120.

(44) Hope, J. M.; Wilson, J. J.; Lippard, S. J. Photoluminescent DNA binding and cytotoxic activity of a platinum(II) complex bearing a tetradentate beta-diketiminate ligand. Dalton Transactions 2013, 42 (9), 3176-80.

(45) Li, J.-L.; Jiang, L.; Wang, B.-W.; Tian, J.-L.; Gu, W.; Liu, X.; Yan, S.-P. Significant differences in the biological activity of mononuclear $\mathrm{Cu}(\mathrm{ii})$ and $\mathrm{Ni}(\mathrm{ii})$ complexes with the polyquinolinyl ligand. New J. Chem. 2015, 39 (1), 529-538.

(46) Zou, C.; Lin, J.; Suo, S.; Xie, M.; Chang, X.; Lu, W. Palladium(ii) N-heterocyclic allenylidene complexes with extended intercationic PdPd interactions and MMLCT phosphorescence. Chem. Commun. 2018, 54 (42), 5319-5322.

(47) Aliprandi, A.; Mauro, M.; De Cola, L. Controlling and imaging biomimetic self-assembly. Nat. Chem. 2016, 8 (1), 10-5.

(48) Wan, Q.; Xia, J.; Lu, W.; Yang, J.; Che, C. M. Kinetically Controlled Self-Assembly of Phosphorescent Au(III) Aggregates and Ligand-to-Metal-Metal Charge Transfer Excited State: A Combined Spectroscopic and DFT/TDDFT Study. J. Am. Chem. Soc. 2019, 141 (29), 11572-11582.

(49) Yin, X.; Warren, S. A.; Pan, Y. T.; Tsao, K. C.; Gray, D. L.; Bertke, J.; Yang, H. A motif for infinite metal atom wires. Angew. Chem., Int. Ed. 2014, 53 (51), 14087-91.

(50) Brouwer, A. M. Standards for photoluminescence quantum yield measurements in solution (IUPAC Technical Report). Pure Appl. Chem. 2011, 83 (12), 2213-2228.

(51) Swietach, P.; Vaughan-Jones, R. D.; Harris, A. L.; Hulikova, A. The chemistry, physiology and pathology of $\mathrm{pH}$ in cancer. Philos. Trans. R. Soc., B 2014, 369 (1638), 20130099.

(52) Lee, J.-Y.; Tsai, M.-C.; Chen, P.-C.; Chen, T.-T.; Chan, K.-L.; Lee, C.-Y.; Lee, R.-K. Thickness Effects on Light Absorption and Scattering for Nanoparticles in the Shape of Hollow Spheres. J. Phys. Chem. C 2015, 119 (46), 25754-25760.

(53) Zhang, S.; Li, J.; Lykotrafitis, G.; Bao, G.; Suresh, S. SizeDependent Endocytosis of Nanoparticles. Adv. Mater. 2009, 21, 419424.

(54) Kou, L.; Sun, J.; Zhai, Y.; He, Z. The endocytosis and intracellular fate of nanomedicines: Implication for rational design. Asian J. Pharm. Sci. 2013, 8 (1), 1-10.

(55) Meijer, M. S.; Talens, V. S.; Hilbers, M. F.; Kieltyka, R. E.; Brouwer, A. M.; Natile, M. M.; Bonnet, S. NIR-Light-Driven Generation of Reactive Oxygen Species Using Ru(II)-Decorated 
Lipid-Encapsulated Upconverting Nanoparticles. Langmuir 2019, 35 (37), 12079-12090.

(56) Karges, J.; Goldner, P.; Gasser, G. Synthesis, Characterization, and Biological Evaluation of Red-Absorbing Fe(II) Polypyridine Complexes. Inorganics 2019, 7 (1), 4.

(57) Zhao, J.; Stenzel, M. H. Entry of nanoparticles into cells: the importance of nanoparticle properties. Polym. Chem. 2018, 9 (3), 259-272.

(58) Yang, J.; Tu, J.; Lamers, G. E. M.; Olsthoorn, R. C. L.; Kros, A. Membrane Fusion Mediated Intracellular Delivery of Lipid Bilayer Coated Mesoporous Silica Nanoparticles. Adv. Healthcare Mater. 2017, 6 (20), 1700759.

(59) Mroz, P.; Yaroslavsky, A.; Kharkwal, G. B.; Hamblin, M. R. Cell death pathways in photodynamic therapy of cancer. Cancers 2011, 3 (2), 2516-39.

(60) Lazzari, G.; Couvreur, P.; Mura, S. Multicellular tumor spheroids: a relevant $3 \mathrm{D}$ model for the in vitro preclinical investigation of polymer nanomedicines. Polym. Chem. 2017, 8 (34), 4947-4969.

(61) Peng, Q.; Moan, J.; Kongshaug, M.; Evensen, J. F.; Anholt, H.; Rimington, C. Sensitizer for photodynamic therapy of cancer: a comparison of the tissue distribution of photofrin II and aluminum phthalocyanine tetrasulfonate in nude mice bearing a human malignant tumor. Int. J. Cancer 1991, 48, 258-264.

(62) Maytin, E. V.; Kaw, U.; Ilyas, M.; Mack, J. A.; Hu, B. Blue light versus red light for photodynamic therapy of basal cell carcinoma in patients with Gorlin syndrome: A bilaterally controlled comparison study. Photodiagn. Photodyn. Ther. 2018, 22, 7-13.

(63) Gholam, P.; Bosselmann, I.; Enk, A.; Fink, C. Impact of red versus blue light on tolerability and efficacy of PDT: a randomized controlled trial. Journal der Deutschen Dermatologischen Gesellschaft 2018, 16 (6), 711-717.

(64) Oltulu, P.; Ince, B.; Kokbudak, N.; Findik, S.; Kilinc, F. Measurement of epidermis, dermis, and total skin thicknesses from six different body regions with a new ethical histometric technique. Turkish Journal of Plastic Surgery 2018, 26 (2), 56.

(65) Ash, C.; Dubec, M.; Donne, K.; Bashford, T. Effect of wavelength and beam width on penetration in light-tissue interaction using computational methods. Lasers in Medical Science 2017, 32 (8), 1909-1918.

(66) Zheng, H. A Review of Progress in Clinical Photodynamic Therapy. Technol. Cancer Res. Treat. 2005, 4 (3), 283-293.

(67) Kaspler, P.; Lazic, S.; Forward, S.; Arenas, Y.; Mandel, A.; Lilge, L. A ruthenium(ii) based photosensitizer and transferrin complexes enhance photo-physical properties, cell uptake, and photodynamic therapy safety and efficacy. Photochemical and Photobiological Sciences 2016, 15 (4), 481-95.

(68) Wan, Q.; To, W. P.; Yang, C.; Che, C. M. The Metal-Metal-toLigand Charge Transfer Excited State and Supramolecular Polymerization of Luminescent Pincer Pd(II) -Isocyanide Complexes. Angew. Chem., Int. Ed. 2018, 57 (12), 3089-3093.

(69) Wehner, M.; Würthner, F. Supramolecular polymerization through kinetic pathway control and living chain growth. Nature Reviews Chemistry 2020, 4 (1), 38-53.

(70) Sindhwani, S.; Syed, A. M.; Ngai, J.; Kingston, B. R.; Maiorino, L.; Rothschild, J.; MacMillan, P.; Zhang, Y.; Rajesh, N. U.; Hoang, T.; Wu, J. L. Y.; Wilhelm, S.; Zilman, A.; Gadde, S.; Sulaiman, A.; Ouyang, B.; Lin, Z.; Wang, L.; Egeblad, M.; Chan, W. C. W. The entry of nanoparticles into solid tumours. Nat. Mater. 2020, 19 (5), $566-575$. 